San Jose State University

SJSU ScholarWorks

Master's Theses

Master's Theses and Graduate Research

Spring 2014

\title{
An Investigation of Coastal Groundwater Discharge and Associated Nutrient Inputs Using Electrical Resistivity, Temperature, and Geochemical Tracers in Pescadero Lagoon, California
}

Christina Maryann Volpi

San Jose State University

Follow this and additional works at: https://scholarworks.sjsu.edu/etd_theses

\section{Recommended Citation}

Volpi, Christina Maryann, "An Investigation of Coastal Groundwater Discharge and Associated Nutrient Inputs Using Electrical Resistivity, Temperature, and Geochemical Tracers in Pescadero Lagoon, California" (2014). Master's Theses. 4443.

DOI: https://doi.org/10.31979/etd.jc8y-m8sq

https://scholarworks.sjsu.edu/etd_theses/4443

This Thesis is brought to you for free and open access by the Master's Theses and Graduate Research at SJSU ScholarWorks. It has been accepted for inclusion in Master's Theses by an authorized administrator of SJSU ScholarWorks. For more information, please contact scholarworks@sjsu.edu. 
AN INVESTIGATION OF COASTAL GROUNDWATER DISCHARGE AND ASSOCIATED NUTRIENT INPUTS USING ELECTRICAL RESISTIVITY, TEMPERATURE, AND GEOCHEMICAL TRACERS IN PESCADERO LAGOON, CALIFORNIA

\author{
A Thesis \\ Presented to \\ The faculty of Moss Landing Marine Laboratories \\ San José State University \\ In Partial Fulfillment \\ of the Requirements for the Degree \\ Master of Science \\ by \\ Christina M. Volpi
}

May 2014 
(C) 2014

Christina M. Volpi

ALL RIGHTS RESERVED 
The Designated Thesis Committee Approves the Thesis Titled

\author{
AN INVESTIGATION OF COASTAL GROUNDWATER DISCHARGE AND \\ ASSOCIATED NUTRIENT INPUTS USING ELECTRICAL RESISTIVITY, \\ TEMPERATURE, AND GEOCHEMICAL TRACERS IN PESCADERO LAGOON, \\ CALIFORNIA \\ by \\ Christina M. Volpi
}

APPROVED FOR MOSS LANDING MARINE LABORATORIES

SAN JOSE STATE UNIVERSITY

MAY 2014

Dr. Erika McPhee-Shaw

Moss Landing Marine Laboratories

Dr. Ivano Aiello

Moss Landing Marine Laboratories

Dr. Peter Swarzenski

United States Geological Survey 


\begin{abstract}
AN INVESTIGATION OF COASTAL GROUNDWATER DISCHARGE AND ASSOCIATED NUTRIENT INPUTS USING ELECTRICAL RESISTIVITY, TEMPERATURE, AND GEOCHEMICAL TRACERS IN PESCADERO LAGOON, CALIFORNIA

By Christina M. Volpi
\end{abstract}

Pescadero Lagoon is a complex lagoon system located on the central California coast in San Mateo County. Over the last decade, external stressors such as degraded water quality, restricted circulation, heightened groundwater withdrawals, changes in the fluvial geomorphology that affect surface water runoff, and widespread agriculture in the watershed have impacted the lagoon. The lagoon system is bounded on the marine side by an ephemeral sand berm that is seasonally closed and so hinders open exchange with the ocean. This berm and the Mediterranean-type climate play an important role in the lagoon's circulation and water quality. The most high-profile and deleterious effect of reduced ocean-lagoon exchange and restricted water circulation is the occurrence of bottom-water low oxygen events that can trigger seasonal fish kills. This project employed a suite of geophysical and geochemical techniques to better understand the role of groundwater on lagoon water and constituent balances. The main objective of this research was to quantify groundwater seepage rates into Pescadero Lagoon across broad spatial and temporal scales using electrical resistivity, temperature, and Radon-222 $\left({ }^{222} \mathrm{Rn}\right)$ as tracers of groundwater movement. Resulting seepage rate estimates were then used to derive associated nutrient flux estimates, which can be compared to atmospheric and riverine nutrient load estimates to yield more comprehensive nutrient budgets. 


\section{ACKNOWLEDGMENTS}

It is impossible to thank all of the people I feel gratitude towards or who have made an imprint on my life up to this point. I would like to start by thanking my advisor, Dr. Erika McPhee-Shaw who helped me immensely through this process. Thank you to my other committee members, Dr. Ivano Aiello who shares in my excitement for geology and Dr. Peter Swarzenki who took an interest in me and made this project possible.

Other members of the Moss Landing Marine Laboratories community I would like to acknowledge are Dr. Kenneth Coale, Craig Hunter, Sara Tanner, and my lab mates as well. From the U.S. Geological Survey, I'd like to thank Christina Richardson and Cordell Johnson for all of your help in the field.

I am indebted to the Colorado School of Mines, where I received my undergraduate degree. The school, faculty, and my classmates challenged me and forced me to become a better scientist and person. A special thanks to Dr. Dave Benson, Dr. Junko Munakata Marr, Dr. Reed Maxwell, Dr. John Humphrey, and Dr. Paul Santi.

I would not be standing here today without the love, encouragement, and support of my friends and family. I'd like to thank my parents, Kirsten and Danny Volpi, thank you for always believing in me even when I didn't believe in myself. My sister, Elise Volpi, thank you for your ability to always brighten my day. Travis Pitcher, thank you for being my rock in which I can depend on; you are not only my boyfriend but my best friend as well.

This master's thesis was completed in two short years, but everyone who has played a role in my life, no matter how small, has contributed and I thank you for that. 


\section{TABLE OF CONENTS}

List of Figures and Tables..........................................................iii

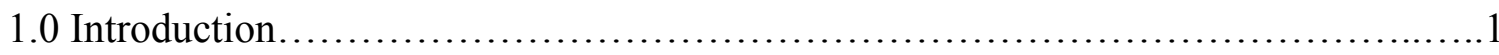

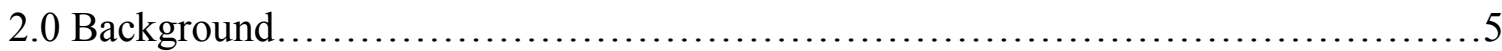

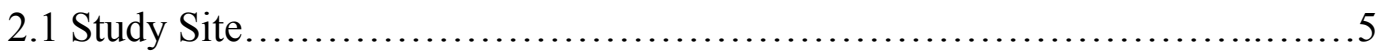

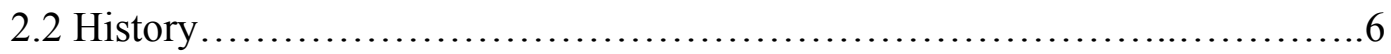

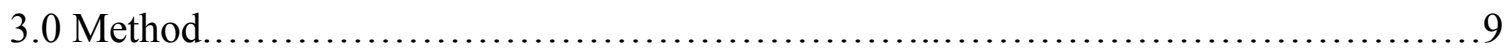

3.1 Groundwater Tracers: Temperature.........................................9

3.2 Groundwater Tracers: Radon.........................................12

3.3 Groundwater Tracers: Electrical Resistivity .............................16

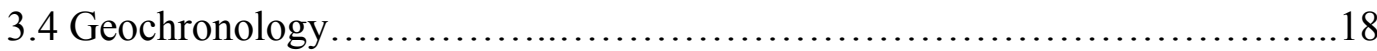

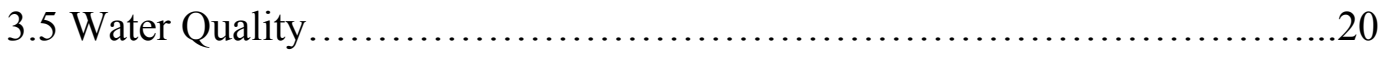

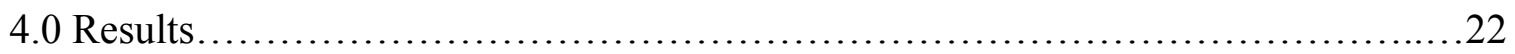

4.1 Groundwater Tracers: Temperature..................................23

4.2 Groundwater Tracers: Radon........................................... 31

4.3 Groundwater Tracers: Electrical Resistivity .............................32

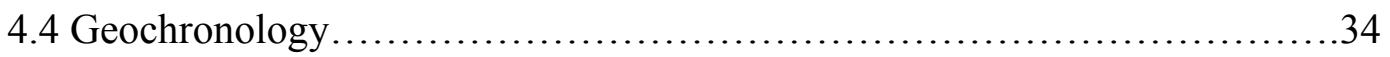

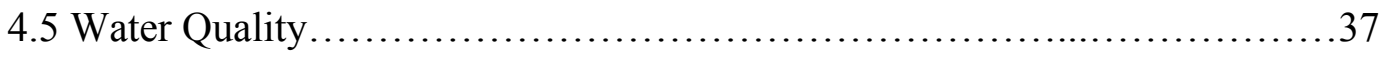

5.0 Discussion and Conclusion.....................................................

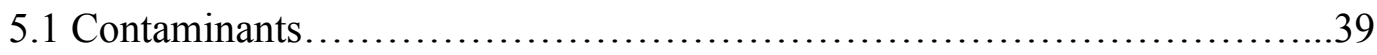

5.2 Groundwater Influx.......................................................

5.3 Sediment Core Analyses...................................................4 


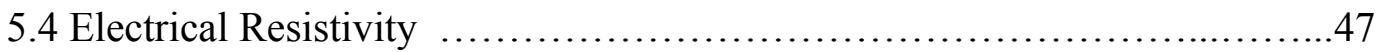

5.5 Implications........................................................ 48

References................................................................... 


\section{LIST OF FIGURES AND TABLES}

Figure 1: Location of Pescadero Lagoon..........................................

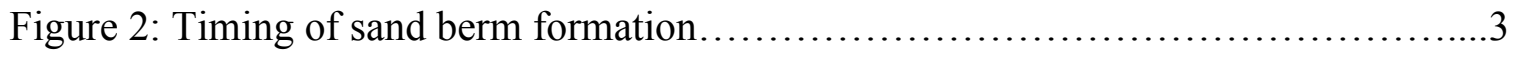

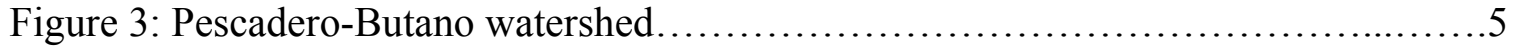

Table 1: Chronology of relevant events......................................

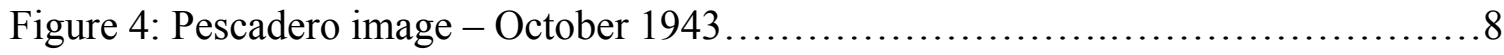

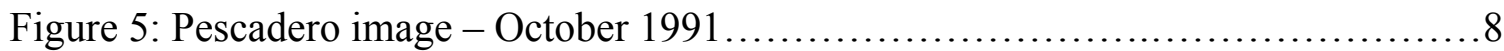

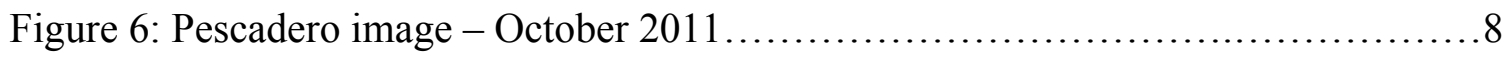

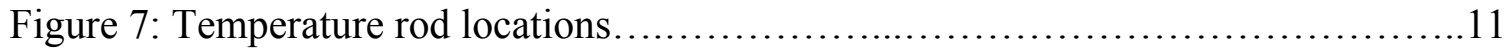

Figure 8: Schematic of temperature rod......................................... 12

Figure 9: Uranium and thorium decay series ................................... 13

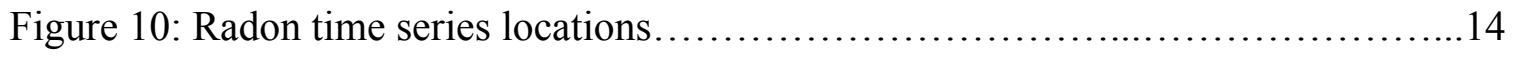

Figure 11: Radon advection-diffusion box model...............................15

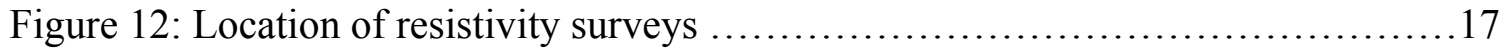

Figure 13: Sediment coring locations.......................................20

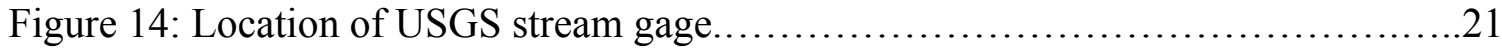

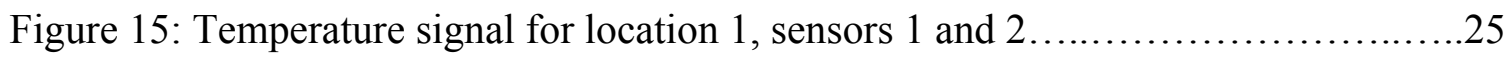

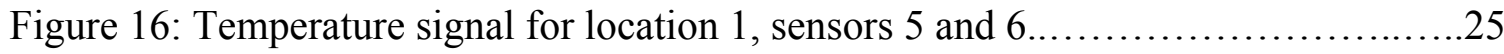

Figure 17: Auto-spectrum analysis for temperature rod 1, sensors 1 and $2 \ldots \ldots \ldots \ldots \ldots . .25$

Figure 18: Auto-spectrum analysis for temperature rod 1, sensors 5 and $6 \ldots \ldots \ldots \ldots . . .25$

Figure 19: Coherence analysis for temperature rod 1, sensors 1 and $2 \ldots \ldots \ldots \ldots \ldots \ldots . \ldots 26$

Figure 20: Coherence analysis for temperature rod 1, sensors 5 and $6 \ldots \ldots \ldots \ldots \ldots \ldots . \ldots 26$ 


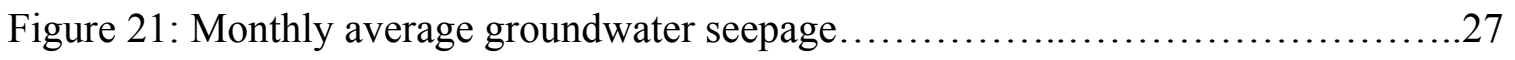

Figure 22: Monthly average groundwater seepage for March at separate locations......27

Figure 23: Total monthly average groundwater seepage at all locations.................28

Figure 24: Total monthly precipitation for San Mateo County.........................29

Figure 25: Monthly average discharge for Pescadero Creek, $1951-2013 \ldots \ldots \ldots \ldots \ldots . . . .30$

Figure 26: Monthly average surface water discharge for Pescadero Creek..............30

Figure 27: Significant wave height near Half Moon Bay ............................ 31

Figure 28: Radon-222 activities measured in the groundwater........................32

Figure 29: Typical electrical conductivity of rocks, minerals, and fluids................33

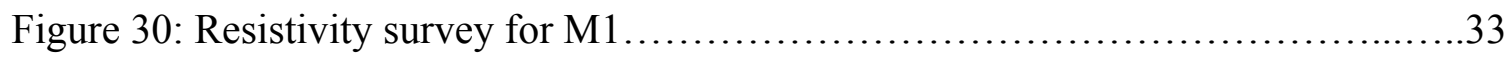

Figure 31: Resistivity survey for A1 ............................................

Figure 32: Resistivity survey for A2 ........................................ 34

Figure 33: Resistivity survey for A3 ....................................... 34

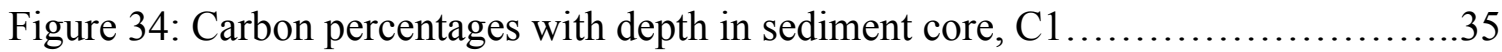

Figure 35: Nitrogen percentages with depth in sediment core, $\mathrm{C} 1 \ldots \ldots \ldots \ldots \ldots \ldots \ldots \ldots . \ldots . \ldots . \ldots . \ldots$

Figure 36: Cesium-137 activities showing a linear sedimentation rate.................36

Figure 37: Lead-210 activities showing a linear sedimentation rate..................36

Figure 38 Lead-210 activities showing a mass accumulation rate..................... 36

Figure 39: Nutrient concentrations in water samples............................. 38

Figure 40: A conceptual model of sulfate reduction in an aquatic environment..........41

Figure 41: SEM image of a pyrite framboid and a partial pennate diatom from a core....42

Figure 42: Image of the manual breach of the sand berm on October $2012 \ldots \ldots \ldots \ldots \ldots . . .48$ 


\subsection{Introduction}

Pescadero Lagoon is a coastal estuary along the northern-central California coast with intermittent surface water access to the ocean (Figure 1). The water body exhibits anoxic and eutrophic conditions seasonally when the sand berm blocks overland flow and thus restricts circulation. Pescadero Lagoon and Pescadero State Beach are recreational areas that serve as a habitat for many animals, including some endangered species such as the San Francisco garter snake. Since 1995, Pescadero Lagoon has been the site for periodic fish kills; mainly steelhead trout, tidewater goby, and staghorn sculpin deaths have been recorded between the late-summer and early-winter months (Frucht, 2013).

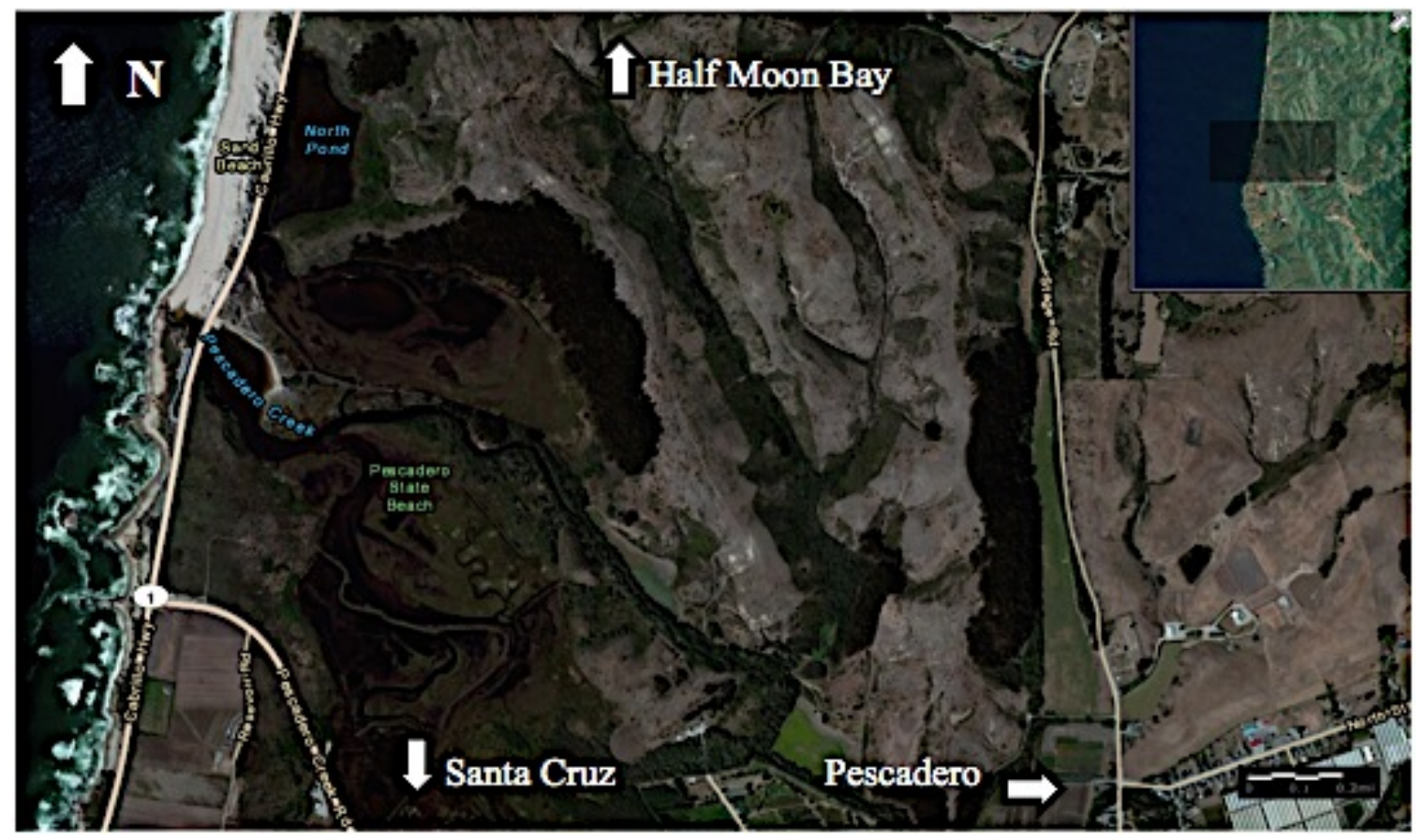

Figure 1: Location of Pescadero Lagoon and relation to nearby areas $\left(37^{\circ} 15^{\prime} 45^{\prime \prime} \mathrm{N}\right.$, $122^{\circ} 24^{\prime} 15^{\prime \prime}$ W). Data obtained from ESRI, ArcGIS. 2014.

Since 2002, Pescadero Watershed was listed as an impaired water body according to the U.S. Environmental Protection Agency (EPA). The Clean Water Act (CWA), 
section 303(d), requires that states must list water bodies that do not meet water quality standards. In 2002, 2004, 2006, and 2010 Pescadero Watershed was listed as impaired due to sedimentation/siltation. The watershed's designated use as a cold freshwater habitat was classified as impaired in 2010. Impairment and the decline in species populations have been correlated with accelerated rates of erosion and sedimentation. Natural geologic processes, climate change, and human land practices are responsible for these accelerated rates (Frucht, 2013).

The timing of the formation and breach of the sand berm are crucial for the health of the lagoon ecosystem. Annual fish kills have been recorded intermittently from 1995 to present day and occur when the estuary becomes cut off from the ocean by an ephemeral sand berm. A general trend over the past two decades has shown sand berm formation occurring later in the dry season (Figure 2). Less freshwater input into the lagoon when the sand berm is in place, allows for density-driven stratification that can trigger bottom water hypoxia or anoxia. The sand berm is breached by increased wave action and an increase in freshwater input; both generally occur in winter months. This creates a mixing event where hypoxic water is transported into the lagoon's water column, sometimes causing annual fish kills. 


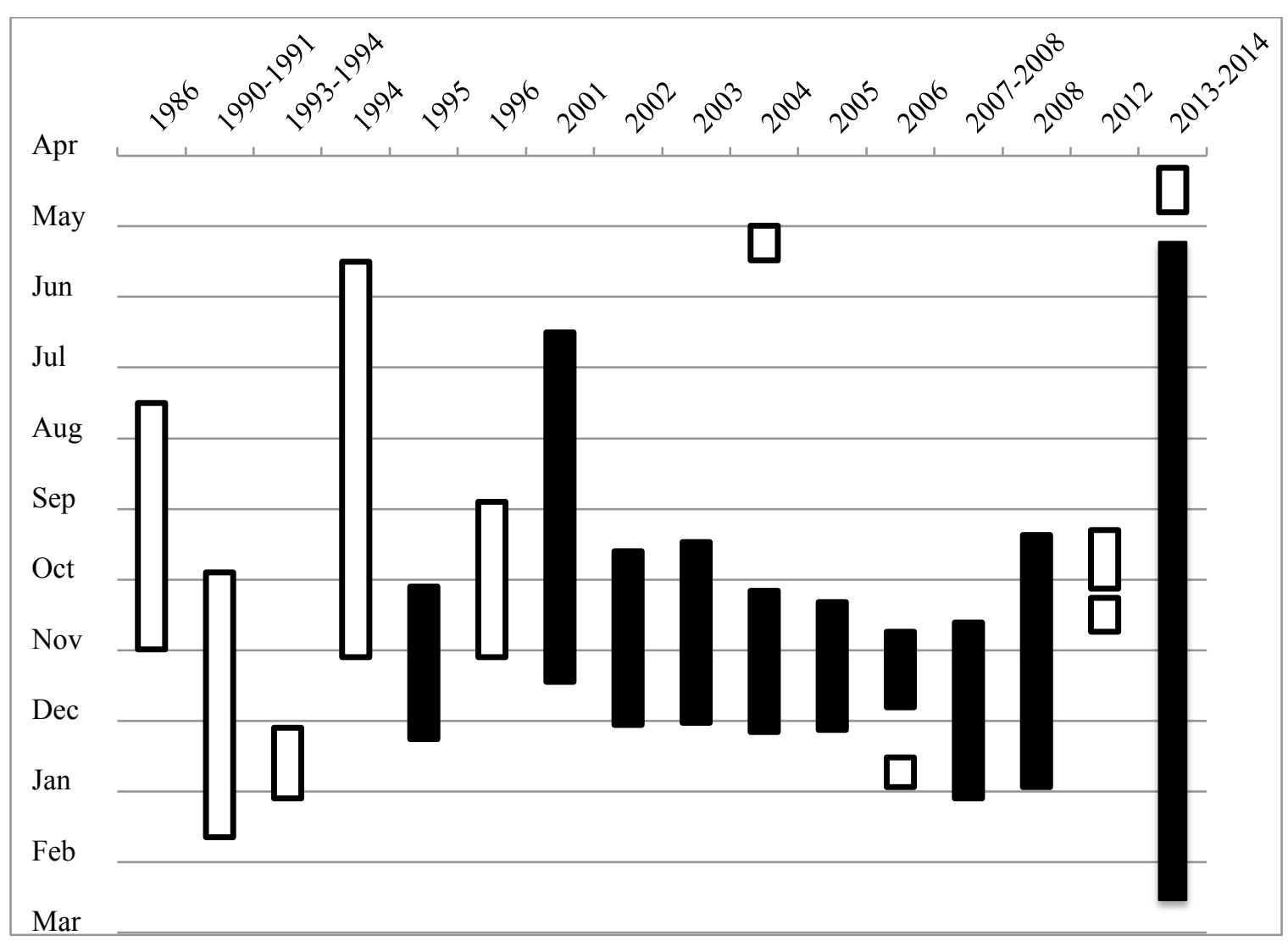

Figure 2: Timing of Sand Berm Formation. Blocks indicate documented periods of time where the estuary has no surficial access to the ocean due to sand berm formation; black blocks indicate reported fish kills during that time period and white blocks indicate no reported fish kills. Data obtained from "Inorganic chemical oxygen demand of resuspended sediments in a bar-built lagoon,” by K. A. Smith. 2009.

By better understanding the hydrological processes that seasonally dominate the lagoon, efforts can be enhanced to mitigate or prevent annual fish kills. Many scientific studies have been conducted at Pescadero Lagoon, but in general groundwater has been a neglected topic of research for this area. Submarine groundwater discharge (SGD) is an important aspect of coastal systems that is often ignored or understudied. The lack of SGD studies in coastal environments is mainly due to the complexity of identifying sources and quantifying rates. Submarine groundwater discharge plays a significant role 
in the function of coastal environments. Groundwater pathways often serve as a primary transportation route for elevated concentrations of nutrients, trace elements, radionuclides, and organic material. This subsurface transportation has been known to be involved in the onset of widespread harmful algae blooms (Swarzenski, Simonds, Paulson, Kruse, \& Reich, 2007). Identifying and quantifying SGD rates is complex, but nonetheless imperative to the understanding of nutrient inputs into a system. Natural geochemical processes such as the decay of ${ }^{222} \mathrm{Rn}$ to ${ }^{228} \mathrm{Ra}$ are used as a groundwater tracer (Swarzenski, Reich, Kroeger, \& Baskaran, 2007). Another natural tracer that can be used to determine seepage rates is heat (Hatch, Fisher, Revenaugh, Constantz, \& Ruehl, 2006). Groundwater outflow through the sand berm can be visualized with the use of directcurrent (DC) electrical resistivity (Swarzenski et al., 2007). Coastal environments present an ideal site to use this method; the saltwater-freshwater interface can be visualized using inversion techniques. Groundwater exchange plays an important role in the delivery and loading of nutrients into coastal environments. Pescadero Lagoon is a prime study site for various SGD methods and the results from this study with allow a better understanding of a complex coastal system. Dating and analyzing sediment cores gives us the ability to better understand the geologic processes that occur in the lagoon today and compare them to changes throughout time. This understanding can help determine the natural state of a lagoon, without human intervention, and present a model for a healthy ecosystem.

This study addressed the following questions: 1) What is the amount of groundwater flux into and out of the system? 2) What is the major source of nutrients 
into the system? 3) Is the major source of nutrients groundwater or surface water derived and at what location(s) are concentrations the highest, and 4) Is there a noticeable physical and/or chemical composition shift in the estuary related to the start of fish kills in recent history?

\subsection{Background}

\subsection{Study Site}

Pescadero Marsh is a brackish-freshwater wetland, which covers a 1.3 square kilometer $\left(\mathrm{km}^{2}\right)$ area. The main freshwater input into the lagoon comes from Pescadero Creek and Butano Creek, with direct input from the east and southeast, respectively. The Pescadero-Butano Watershed feeds the lagoon and drains approximately $210 \mathrm{~km}^{2}$ (Frucht, 2013). The watershed covers northern Santa Cruz County and southern San Mateo County and includes runoff from the Santa Cruz Mountains (Figure 3).

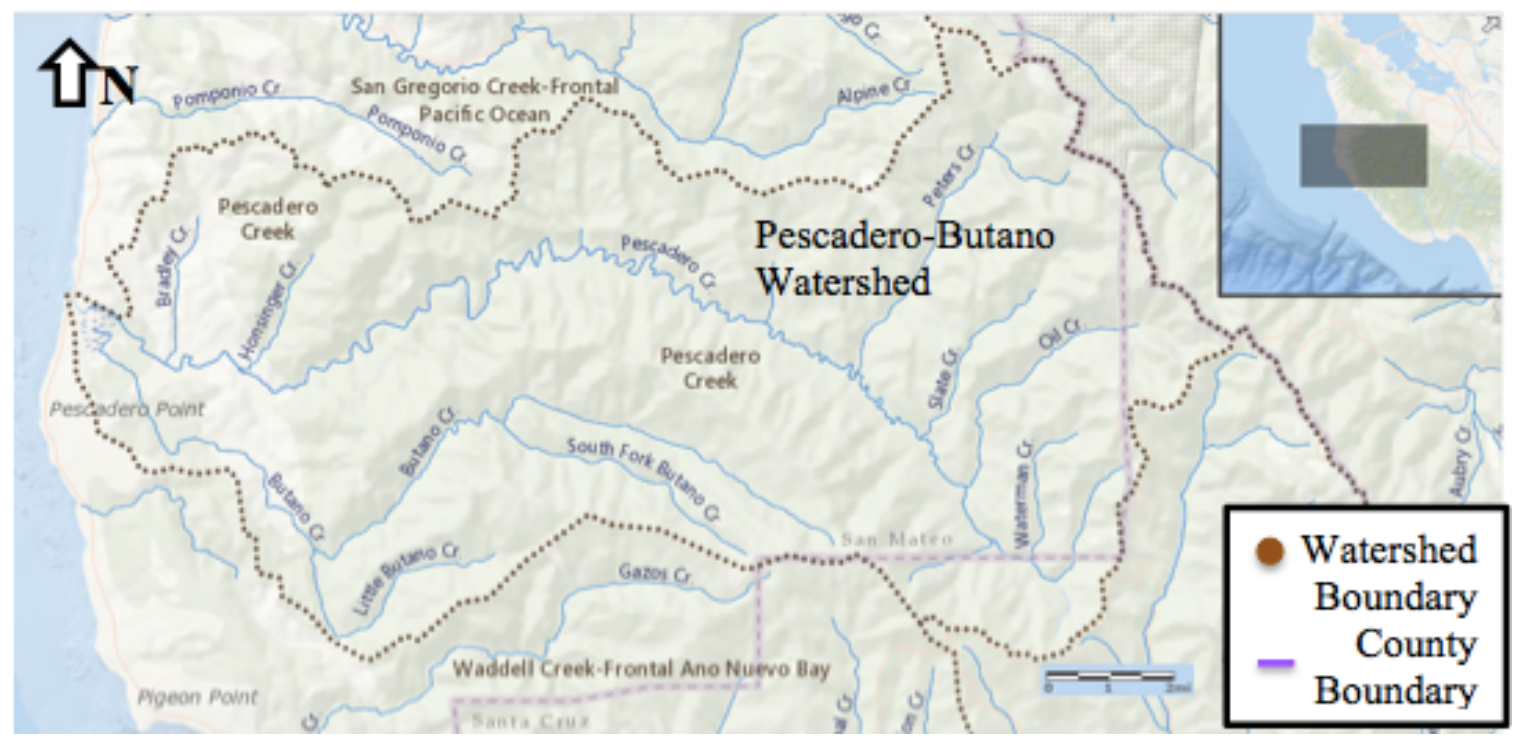

Figure 3: Pescadero-Butano Watershed (37 $\left.15^{\prime} 30^{\prime \prime} \mathrm{N}, 122^{\circ} 16^{\prime} 20^{\prime \prime} \mathrm{W}\right)$. Data obtained from ESRI, ArcGIS. 2014. 
The head of the drainage basin is located approximately 29 kilometers $(\mathrm{km})$ inland from the coast in the Santa Cruz Mountains. Just to the east of the watershed lies the San Andreas Fault, and the San Gregorio fault runs through the western portion of the watershed. The tectonic activity of the area contributes to uplifting and folding, which increases erosion.

The rock outcrops in these mountains consist of marine sandstones, shale, mudstones, basalt, and other volcanics, which have a high susceptibility for erosion. With already high natural erosion rates, these rates are only exacerbated with human input such as agriculture, deforestation, and development in the surrounding area.

\subsection{History}

Pescadero Lagoon's land use history is important for this study because many man-made alterations to the waterways and surrounding areas have a large impact on the ecosystem. Since 1820 this area has been used for agriculture and ranching. Industries in this area grew to include logging, tourism, and recreation. These industries create problems for the water body; agriculture and ranching introduce high concentrations of nutrients into the system, and deforestation creates unstable slopes and erosion. Two occurrences in 1993 may have contributed to the degradation of the lagoon. The California Department of Parks and Recreation attempted to hydrologically restore the lagoon, and the California Department of Transportation replaced the Highway 1 bridge, which altered the shape of the mouth of the estuary (Smith, 2009). Starting in 1995, annual fish kills were reported and have occurred almost every year since. Starting in 
2012, scientists and volunteers made efforts to prevent annual fish kills. In the fall of 2012, scientists and volunteers manually breached the sand berm. The mouth stayed open for two weeks, which proved to be enough time to prevent another annual fish kill. The sand berm stayed closed most recently from May 2013 to February 2014 due to a drought; steelhead trout were captured near the mouth of the lagoon and transported to the ocean to protect their fragile population (Table 1). Figures 4 to 6 show a visual history of the area. The images are from 1942, 1991, and 2011 all of which were taken in October, for a similar seasonality comparison. The major geomorphological change in the time frame is the shrinking channel area of Pescadero Creek. Also there is a clear disconnect between the North Pond, North Marsh, and the rest of the system in the 1943 and 1991 image, hydrologic connectivity was restored in the 2011 image. In the 1990s California Parks and Recreation was tasked with reestablishing hydrologic connectivity in Pescadero Lagoon; this was done by an installment of various levees, dikes, and culverts.

Table 1: Chronology of relevant events in Pescadero-Butano Watershed

\begin{tabular}{|l|l|}
\hline Date & Event \\
\hline $1820-$ Present & Agriculture and ranching \\
\hline $1850-1970$ & Logging \\
\hline $1860-1940$ & Tourism, hunting, and fishing \\
\hline $1990-$ Present & Tourism, camping, and hiking \\
\hline 1993 & California Department of Transportation replaced Highway 1 bridge \\
\hline $1993-1997$ & California Department of Parks and Recreation restoration \\
\hline 1995 & Reported annual fish kills \\
\hline Fall 2012 & Successful manual sand berm breach \\
\hline Summer 2013 & Catch and release of steelhead trout, moved from lagoon to ocean \\
\hline $2013-2014$ & Drought year and the sand berm was closed for nine months \\
\hline
\end{tabular}




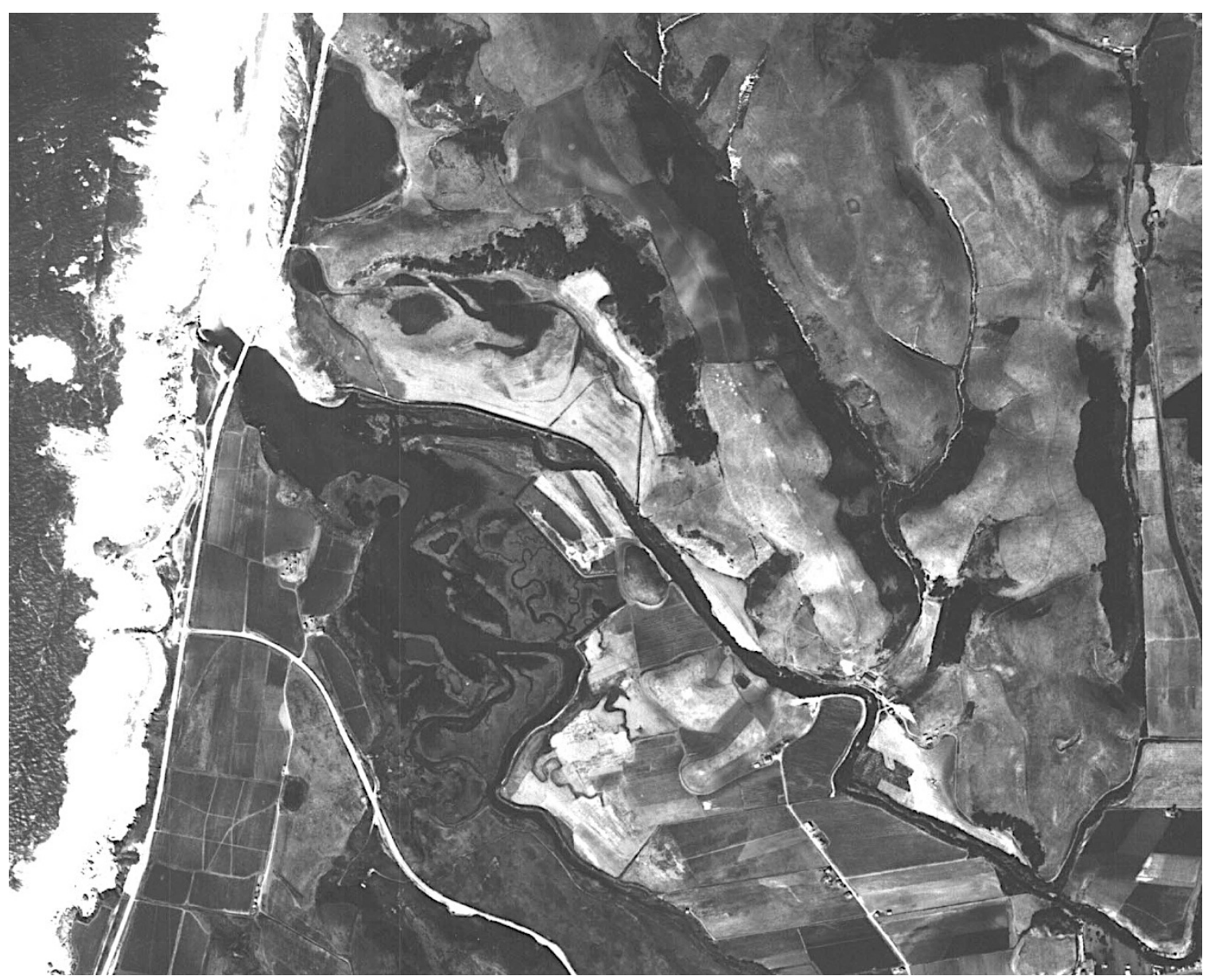

Figure 4: Aerial photograph taken October 1943 over Pescadero Lagoon (37¹6’01" N, $122^{\circ} 24$ '18" W). Adapted from "San Mateo County, California Aerial Photography 1943”, USDA, Agricultural Adjustment Administration. 1943.

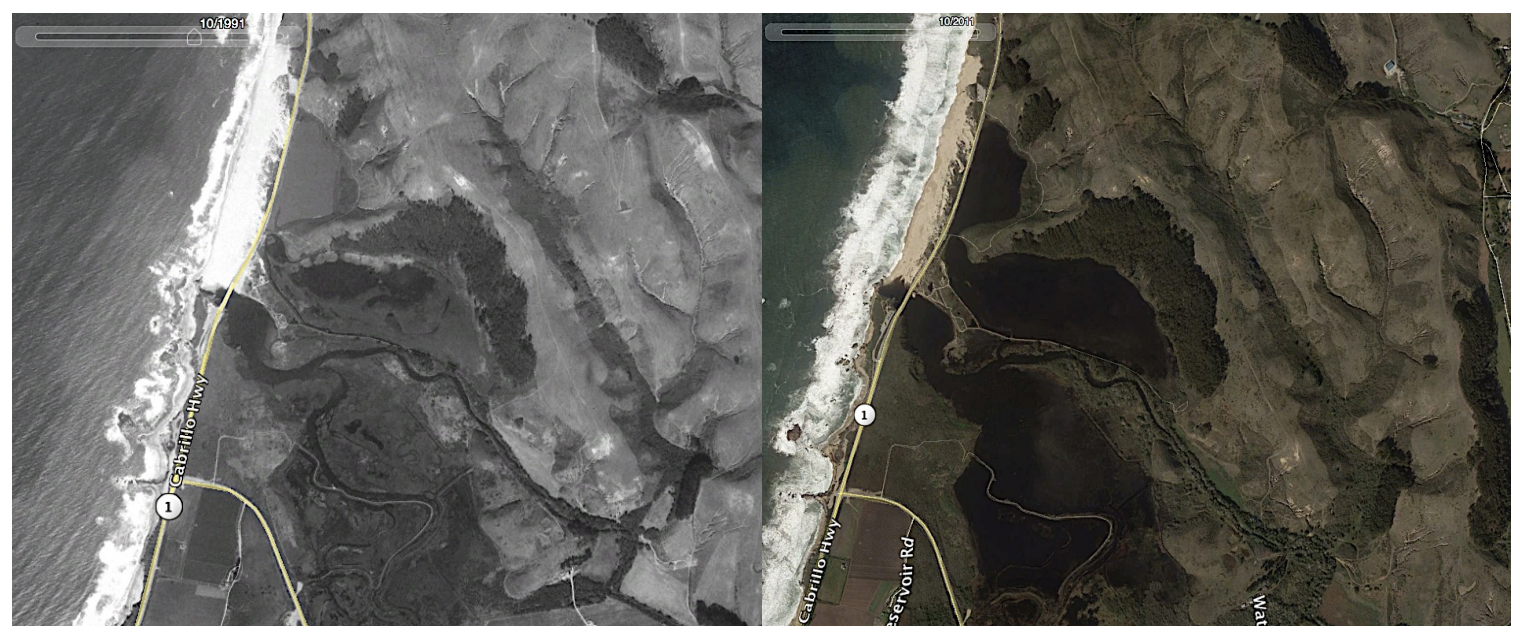

Figure 5 and 6: Satellite image taken October 1991(left) and 2011 (right) over Pescadero Lagoon (37'16’01” N, 122²4'18” W). Adapted from Google Earth. 2014. 


\subsection{Method}

Multiple field methods were used to quantify the groundwater flux into the system. With the various methods described below, the following objectives were addressed: groundwater and surface water inflow, groundwater outflow when the estuary was closed to the ocean, a water budget for the system, sedimentation rates in the lagoon, and nutrient concentration in the water and sediment.

\subsection{Groundwater Tracers: Temperature}

Using thermal data as a groundwater tracer has been recognized as a scientific method as early as 1965 and has been used frequently (Bredehoeft \& Papadopulos, 1965). The small amount of heat-flux within the earth affects groundwater flow and an analytical approach to quantifying this was suggested by Bredehoeft and Papadopulos (1965). Applying this method to groundwater-surface water interactions has been used since 1989; Lapham (1989) tested three sites in the Eastern United States to determine the feasibility of using the natural fluctuation and transfer of heat in a riverbed to determine the rate of groundwater flow of the stream and underlying sediments and the effective vertical hydraulic conductivity of the sediments. There are numerous methods used to access streambed seepage such as differential gauging, seepage meters, shallow piezometers, and tracer injection experiments (Bencala, McKnight, \& Zellweger, 1990; Clark, Schlosser, Stute, \& Simpson, 1996; Lee \& Cherry, 1978; Rosenberry \& Morin, 2004). Each of these methods exhibits various pros and cons to determining groundwater seepage. The thermal method was chosen for this experiment due to its particular ease of 
installation, lack of monitoring and maintenance required, and a several month data record can easily be attained.

Temperature is a naturally occurring, ideal groundwater tracer because it allows for accurate, high resolution, and reliable data collection that is relatively easy, it requires little maintenance, and it is low in cost. The rapid and large range in ambient temperature allows for a clear and measurable thermal signal. The atmosphere and surface water temperature vary throughout the day and night; this signal is transported into the streambed sediment through the porous sediment. The downward advection of heat shows a distinct diurnal pattern that dampens with increasing depth in the water table (Constantz \& Stonestrom, 2003). Temperature measurements in shallow sediment allow us to quantify vertical one-directional groundwater seepage rates.

Temperature rods were placed at seven locations in Pescadero Lagoon; TR3, TR4, TR5, TR6, and TR7 were placed in the marsh area and TR1 and TR2 were placed in the main channel fed by the creek (Figure 7). The locations were selected for a large spatial coverage of the lagoon. These temperature rods were placed into saturated sediment and left out for several months, collecting temperature data at 15-minute intervals. Each temperature rod has six temperature sensors that collect data at various depths; the total length from the first to last sensor is one meter (m) (Figure 8). I developed MATLAB R2012 a programs to determine lag time between the sensors and streambed seepage rates. I wrote an auto-spectrum program to determine the frequency of the signal produced by the time series. I also developed a program to calculate coherence and phase of the temperature signal. The auto-spectrum program was able to pick out a prominent 
peak of one cycle per day in a dataset containing ten months of data at a sampling frequency of 15 minutes within our temperature rod data. The coherence program calculates how repeatable the signal is at a given interval and the phase computed is used to calculate the lag between shallow and deep sensors. Hatch et al. (2006) developed the method and model used to calculate streambed seepage rates. The model calculates vertical streambed seepage from quantifying changes in phase and amplitude of temperature changes with depth, but it requires users to visually select temperature peaks. Schmidt, Fisher, Racz, Lockwood, and Huertos (2011) used this method to link denitrification and infiltration rates during managed groundwater recharge at Harkins Slough, CA.

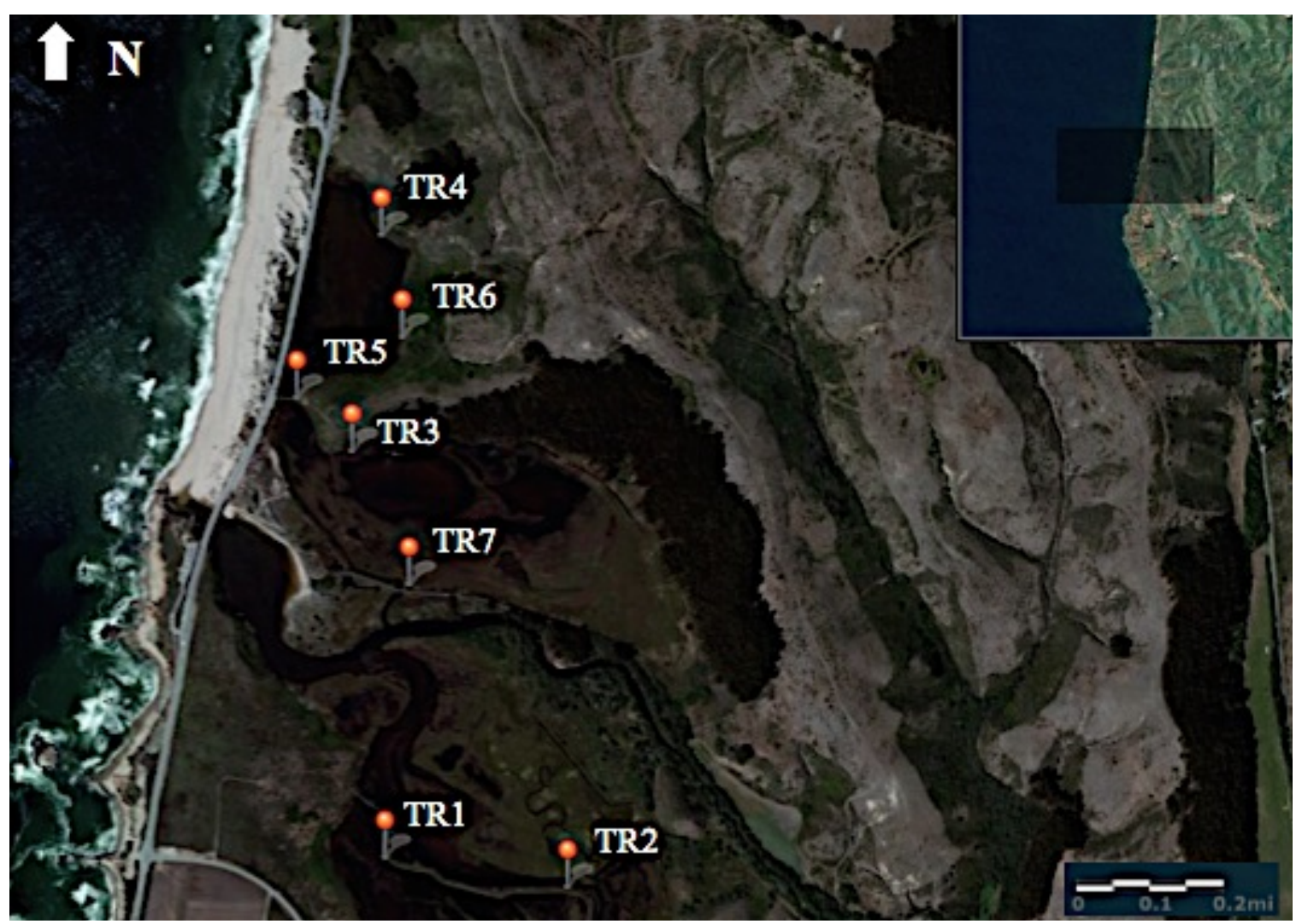

Figure 7: Temperature rod locations in Pescadero Lagoon, CA (37 $16^{\prime} 01^{\prime \prime} \mathrm{N}, 122^{\circ} 24^{\prime} 18^{\prime \prime}$ W). Data obtained from ESRI, ArcGIS. 2014. 


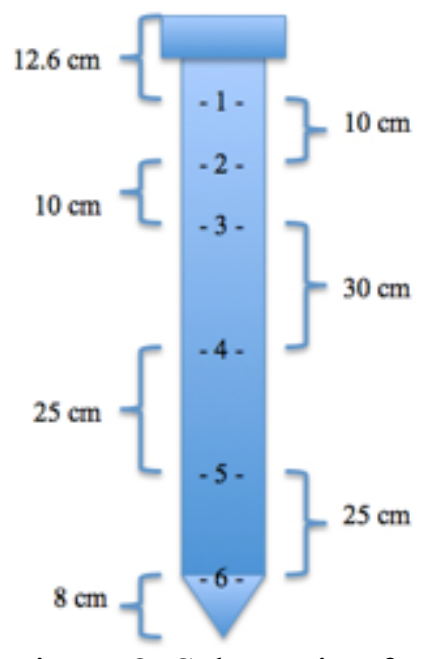

Figure 8: Schematic of a custom temperature rod, showing the vertical placement of the six thermistors (side profile, not to scale).

\subsection{Groundwater Tracers: Radon}

Like temperature, radon can be used as a groundwater tracer. Radon is an inert noble gas with a short half-life $\left(\mathrm{t}_{1 / 2}=3.8\right.$ days), naturally occurring and very abundant in groundwater, and low in surface water because it escapes into the atmosphere (Figure 9). All of these qualities make it an ideal groundwater tracer. An electronic radon meter (Durridge RAD7) was placed in the field for several days to monitor the concentration levels of radon in the groundwater. Two locations were chosen for a surface water radon time series and another location was chosen for a groundwater radon time series (Figure 10). All locations were chosen for there accessibility and we were able to ensure the equipment would stay dry; the groundwater location required an area with coarser material so the piezometer screen would no get clogged with clay or silt. This was conducted to quantify seepage rates into the lagoon and compare results with the temperature rod method. 


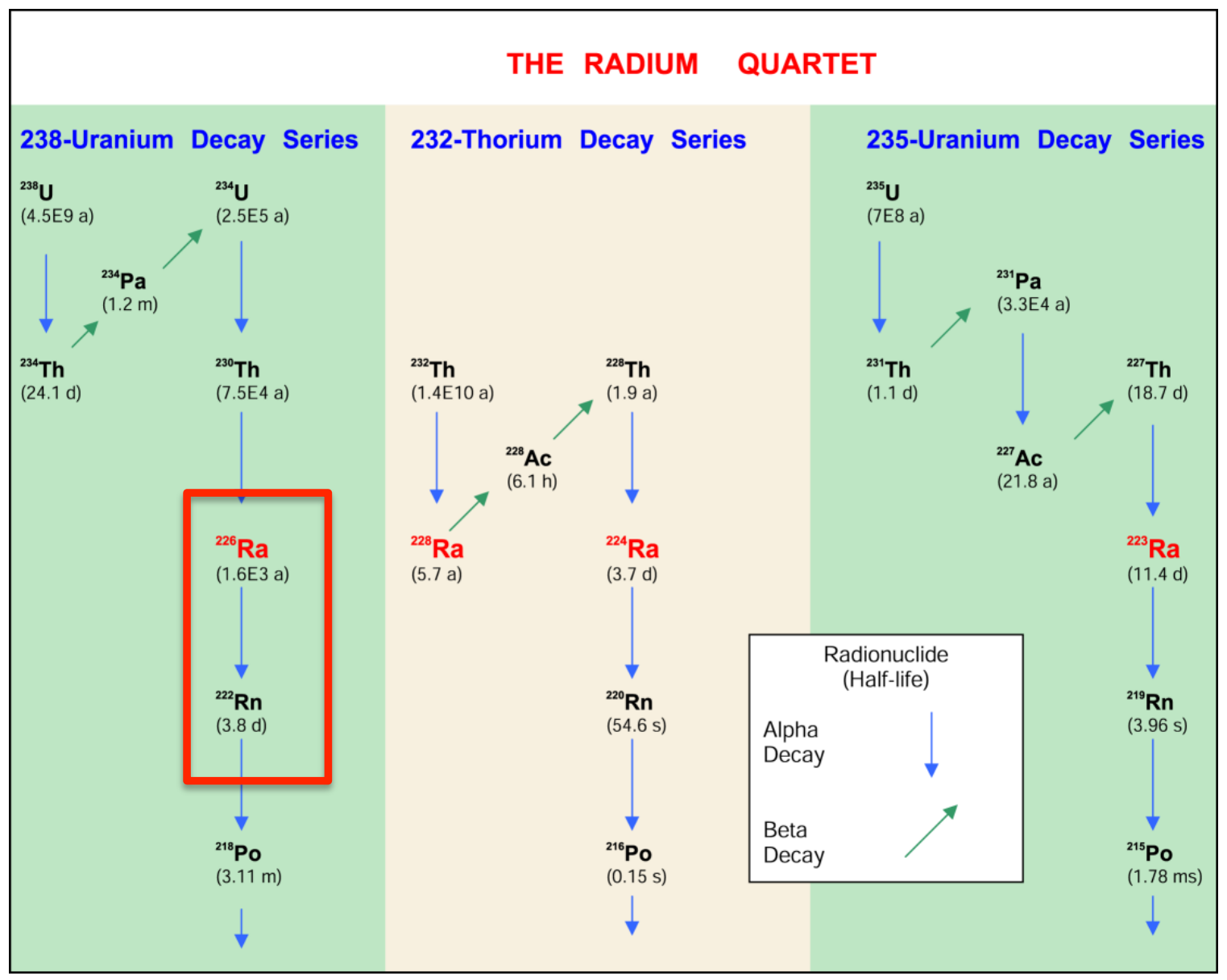

Figure 9: The radium quartet: uranium and thorium decay series, highlighting the decay of radium to radon. Adapted from "U/Th Series Radionuclides as Coastal Groundwater Tracer,” by P. W. Swarzenski. 2007. 


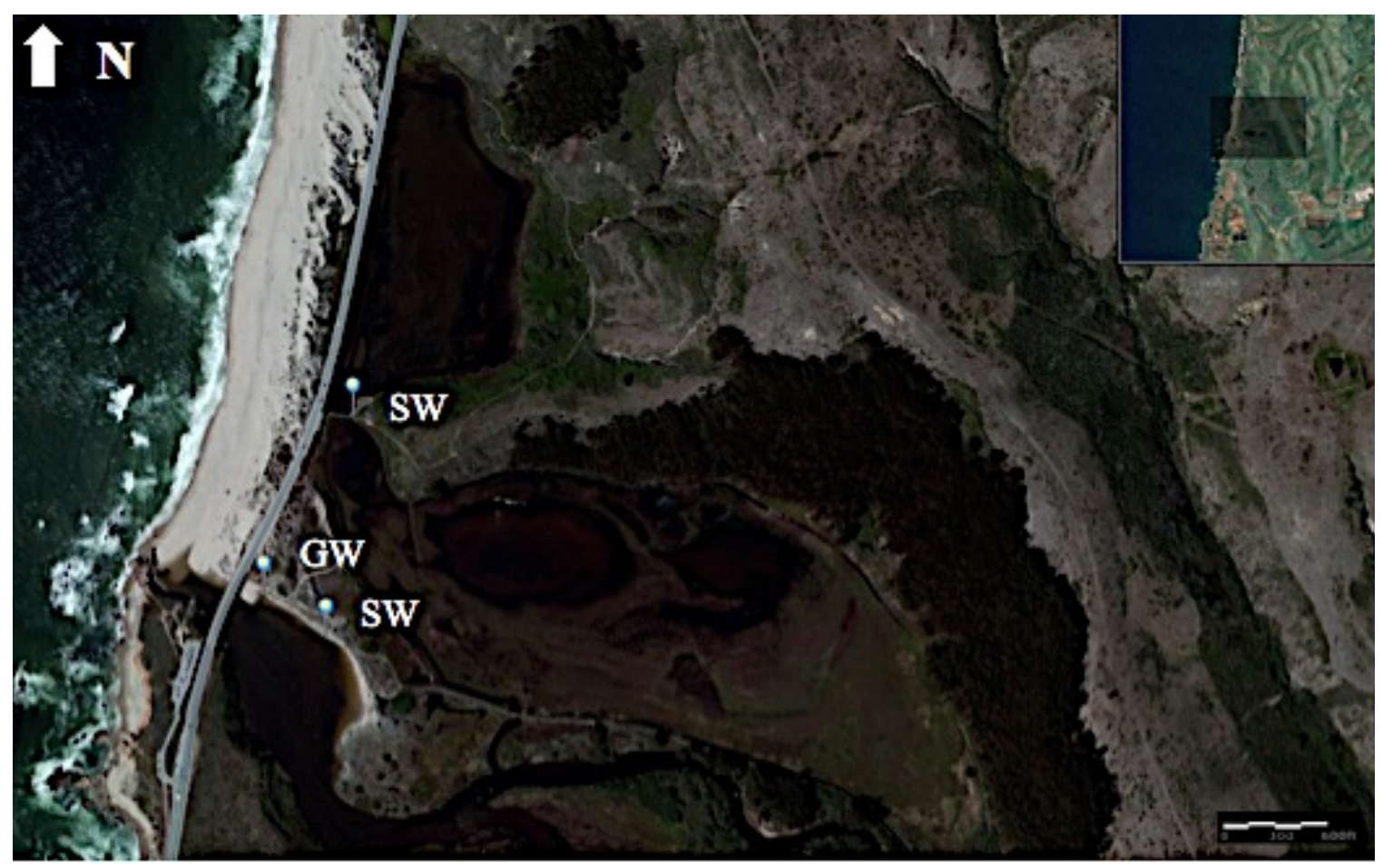

Figure 10: Radon time series stations for surface water (SW) and groundwater (GW) at Pescadero Lagoon, CA $\left(37^{\circ} 16^{\prime} 01^{\prime}\right.$ N , 122 $24^{\prime} 18^{\prime}$ W). Data obtained from ESRI, ArcGIS. 2014.

The estimations for groundwater discharge in these lakes are based on a radon advection-diffusion model (Figure 11). The model was initially developed by Cable, Burnett, Chanton, and Weatherly (1996) and validated many times by multiple direct seepage measurements in marine environments (Burnett et al., 2006). It is basically a mass balance box model that accounts for all radon sinks and sources including diffusion through the sediment-water interface. Thus, in order to construct radon mass balance one should have estimations for the all possible sources and sinks including: (1) radon concentration in the surface waters; (2) radon concentration in the groundwater flowing into the lake, the groundwater end-member; (3) the water depth in order to calculate the radon inventories in the lake water; (4) the concentration of radon in air and average wind 
speed over the lake area for estimation of the atmospheric loses; and (5) the area of the lake. To evaluate the diffusive flux through the sediment-water interface, sediments from the lake bottom may be collected to assess specific hydrogeologic properties such as wet bulk density, porosity, ${ }^{226} \mathrm{Ra}$ content etc. In cases where groundwater advection is significant, inputs via diffusion can usually be ignored. In this application of the radon tracer approach we assume that groundwater discharge into the lakes is in steady state, at least over a period of days to weeks, and it is the only one substantial source of radon into the water column. To collect information about the radon in lake water concentration, we used a one-detector RAD AQUA instrumentation as described in ( Dulaiova, Peterson, Burnett, \& Lane-Smith, 2005). We set up this automatic continuous measuring system on a small bridge. We also collect measurements of temperature and conductivity from the bottom and the surface of the lake water column to check for possible stratification.

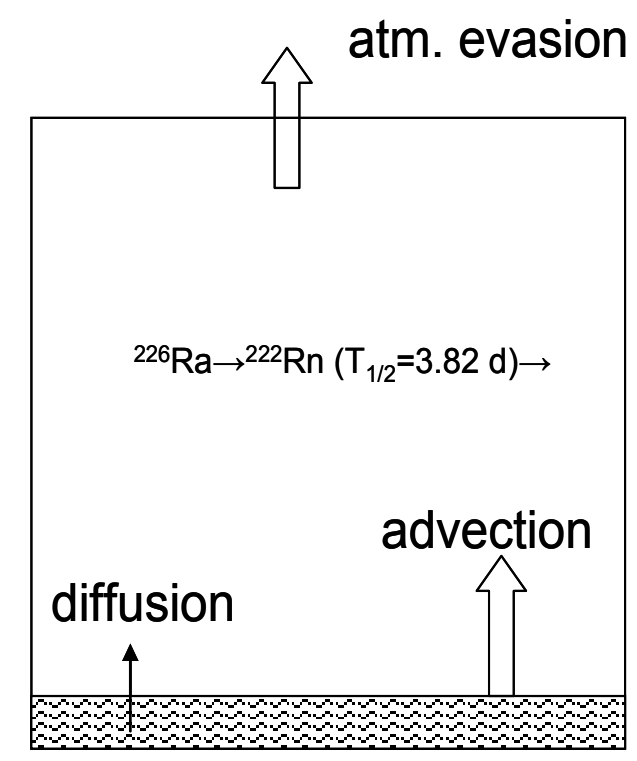

Figure 11: Radon advection-diffusion box model. 
The evaluation of radon atmospheric loss is based on temperature and wind velocity measurements and the air-water radon gradient (MacIntyre, Wanninkhof, \& Chanton, 1995). The atmospheric flux-loss of radon through the water/air interface is proportional to the concentration gradient of radon in air $\left(\mathrm{C}_{a}\right)$ and radon in surface water $\left(\mathrm{C}_{w}\right)$ and the gas transfer coefficient $\mathrm{k}$ :

$$
\operatorname{Flux}_{(a t m)}=\mathrm{k} *\left(\mathrm{C}_{w}-\alpha * \mathrm{C}_{a}\right)
$$

Where $\mathrm{k}$ is a gas transfer coefficient ( $\mathrm{m} /$ day) and $\alpha$ is Ostwald's solubility coefficient:

$$
\begin{aligned}
& \mathrm{k}(600)=0.45 * \mathrm{u}_{10}{ }^{1.6} *\left(\mathrm{~S}_{\mathrm{c}} / 600\right)^{-\mathrm{b}} \\
& \alpha=0.105+0.405 * \exp (-0.05027 * \mathrm{~T})
\end{aligned}
$$

Where: $\mathrm{b}=0.5$ for wind speed $>3.6 \mathrm{~m} / \mathrm{s}$ or $\mathrm{b}=0.667$ for wind speed $<3.6 \mathrm{~m} / \mathrm{s} ; \mathrm{S}_{\mathrm{c}}=$ the Schmidt number (ratio of the kinematic viscosity, $v$, to the molecular diffusion coefficient, $D_{m}\left(v / D_{m}\right) ; u_{10}=$ the wind speed at $10 \mathrm{~m}$ above ground $(\mathrm{m} / \mathrm{s})$; and $\mathrm{T}\left({ }^{\circ} \mathrm{C}\right)$ is the temperature at the water-gas interface. In most of the cases we acquire wind speed data from the closest deployed weather station. We often compare the data from several stations around the area to validate the quality of the measurements.

\subsection{Groundwater Tracers: Electrical Resistivity}

Multi-channel electrical resistivity surveys can be used to determine lithologic boundaries as well as the interface between freshwater and saltwater. The conductivity of saltwater is greater than that of freshwater due to the greater amount of dissolved ions, which can be mapped using a surface electrical resistivity survey. Electrical potential in the ground around a current-carrying electrode depends on the electrical resistivities and 
distribution of the surrounding soils and rocks; minerals are relatively poor conductors so pore water within the sediment is used to measure resistivity differences. A direct current (DC) is applied between electrodes in a linear fashion. A resistivity survey was conducted perpendicular to shore, along the north bank of the estuary. The survey was conducted on March 8, 2013 (the sand berm had not formed at this time) at low tide in order to see the seepage out of the estuary. A second resistivity survey was conducted when the sand berm had blocked surface water exchange between the estuary and ocean which gives a more accurate representation of groundwater seepage through the sand berm without the influence of the surface water (Figure 12).

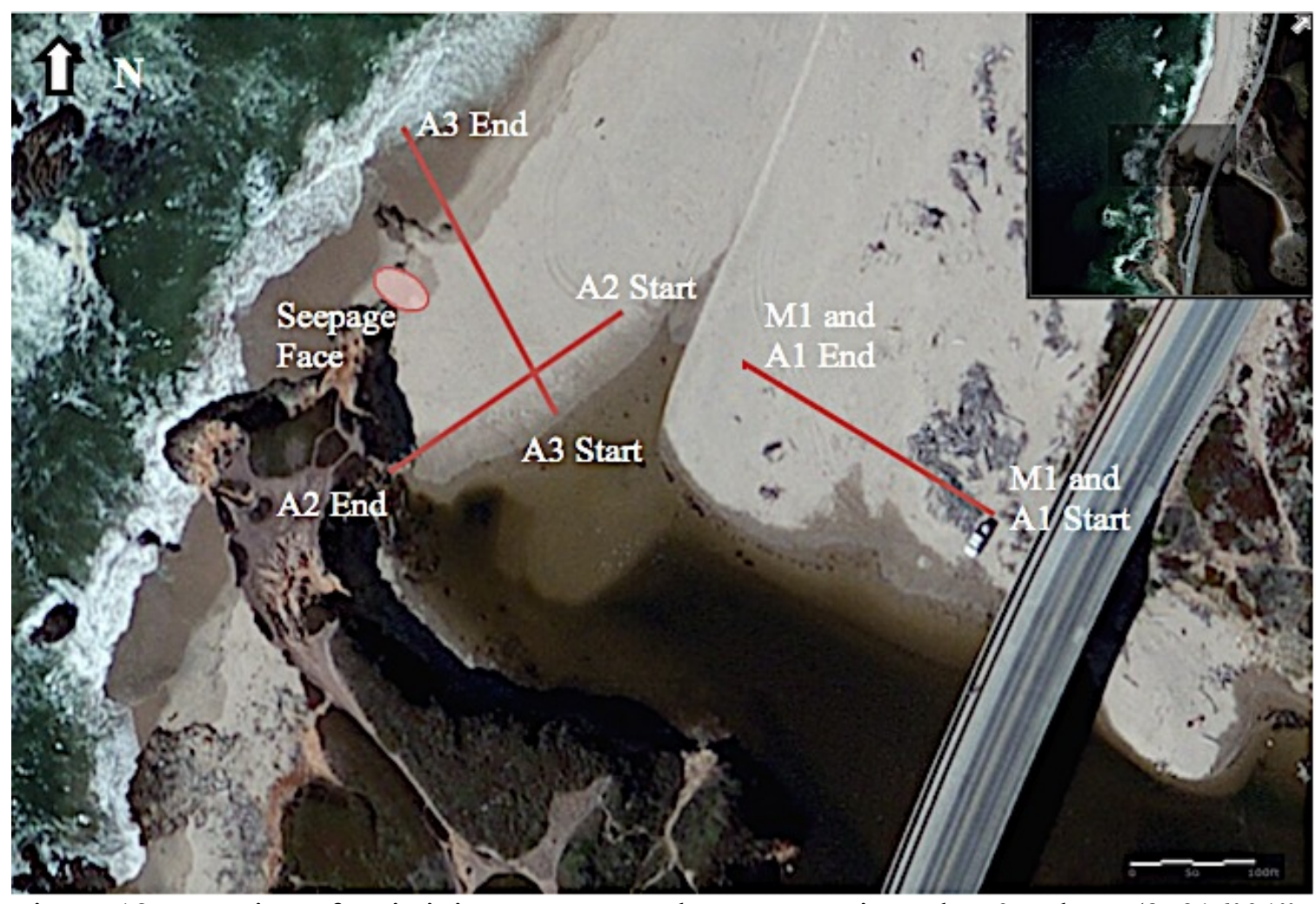

Figure 12: Location of resistivity surveys, each are approximately $50 \mathrm{~m}$ long $\left(37^{\circ} 16^{\prime} 01^{\prime \prime}\right.$ N, 122 $24^{\prime} 42^{\prime \prime}$ W). Lines Al, A2, and A3 were conducted on August 13, 2013 and line M1 was conducted on March 8, 2013. The seepage face was identified in August. Data obtained from ESRI, ArcGIS. 2014. 


\subsection{Geochronology}

Lead-210 (Pb-210) is a natural radioactive form of lead, which is found in small quantities in most soils as part of the uranium decay series. $\mathrm{Pb}-210$ is typically used to date recently deposited sediment cores, especially in slow moving water bodies, such as marshes. Cesiums-137 (Cs-137) is deposited in faster moving water bodies such as rivers, so Cs-137 and $\mathrm{Pb}-210$ are used in conjunction to date cores deposited in coastal water bodies for maximum chronology information (Jeter, 2000). Excess Pb-210 activities are measured with depth in the sediment core, since the rate of decay is consistent with time and a constant sedimentation rate is assumed we can calculate a linear sedimentation rate. Various observational and mechanical methods were used in collecting and analyzing sediment samples. Sediment samples were collected from six different locations in Pescadero Lagoon to get a fair spatial representation (Figure 13). Coring locations were chosen for accessibility as well as to understand the dynamics of the North Pond and lagoon. Three types of coring methods were used; two hand held push core liners of different sizes were used, one of which produced a 30 centimeter $(\mathrm{cm})$ core, the other produced three $16 \mathrm{~cm}$ cores, and a vibracorer was used to produce two $2 \mathrm{~m}$ cores. The $30 \mathrm{~cm}$ core (C1) was collected on June 7, 2013, the three $15 \mathrm{~cm}$ cores (MC1, MC2, and MC3) were collected on October 22, 2013, and the $2 \mathrm{~m}$ cores (VC1 and VC2) were collected on November 14, 2013. The push liner uses manual force exerted to push the core into the sediment and the cap on the top of the liner creates suction so the sediment can be extracted. The vibracorer relies on a tripod for stability and a compressor around a metal pipe is used to vibrate while the pipe is being forced into the 
sediment. To extract the pipe a cap is placed on the top to create a vacuum while a set of pulleys are used to pull the core out. The push liner method uses minimal equipment and personnel making it a better method for collecting multiple cores, whereas the vibracoring method requires more equipment and personnel but there is the potential of extracting a much longer core.

In the laboratory, various methods were used to analyze different properties of the sediment collected. Core logging was an observational method used to describe the core, the laser diffraction particle size analyzer was used to determine grain size, the $\mathrm{CHN}$ analyzer was used to determine carbon and nitrogen percentages of the sediment, a gamma detector was used to measure naturally occurring excess amounts of $\mathrm{Pb}-210$ and Cs-137 to give an estimated sedimentation rate, and the petrographic microscope, scanning electron microscope (SEM), and energy-dispersive x-ray (EDX) were used to look at the composition of the sample in detail.

For the isotope analysis the $30 \mathrm{~cm}$ core was cut into one $\mathrm{cm}$ sections for the first $20 \mathrm{~cm}$, and after that, five $\mathrm{cm}$ sections were cut. These sections were weighed and dried, and were analyzed for trace metals and isotopes. Lead and cesium isotopes ( $\mathrm{Pb}-210$ and Cs-137) found in the sediment were used to calculate sedimentation rates in the lagoon, and carbon and nitrogen percentages were used to determine productivity and nutrient concentrations over time. Each section of the core was analyzed for carbon, nitrogen, and hydrogen percentages in the sediment. For all of the cores smear slides were made and viewed under a petrographic microscope and samples were prepared for the scanning 
electron microscope (SEM) and the energy-dispersive $\mathrm{x}$-ray (EDX), which were used to analyze the sediment for biogenic material and minerals found in the sediment.

To date the core I utilized a similar method described by Smoak and Swarzenski (2004), to analyze the sediment cores recovered from the lagoon. They describe dating cores by using $\mathrm{Pb}-210$ and $\mathrm{Cs}-137$ activities to determine sediment and nutrient accumulation (Smoak \& Swarzenski, 2004).

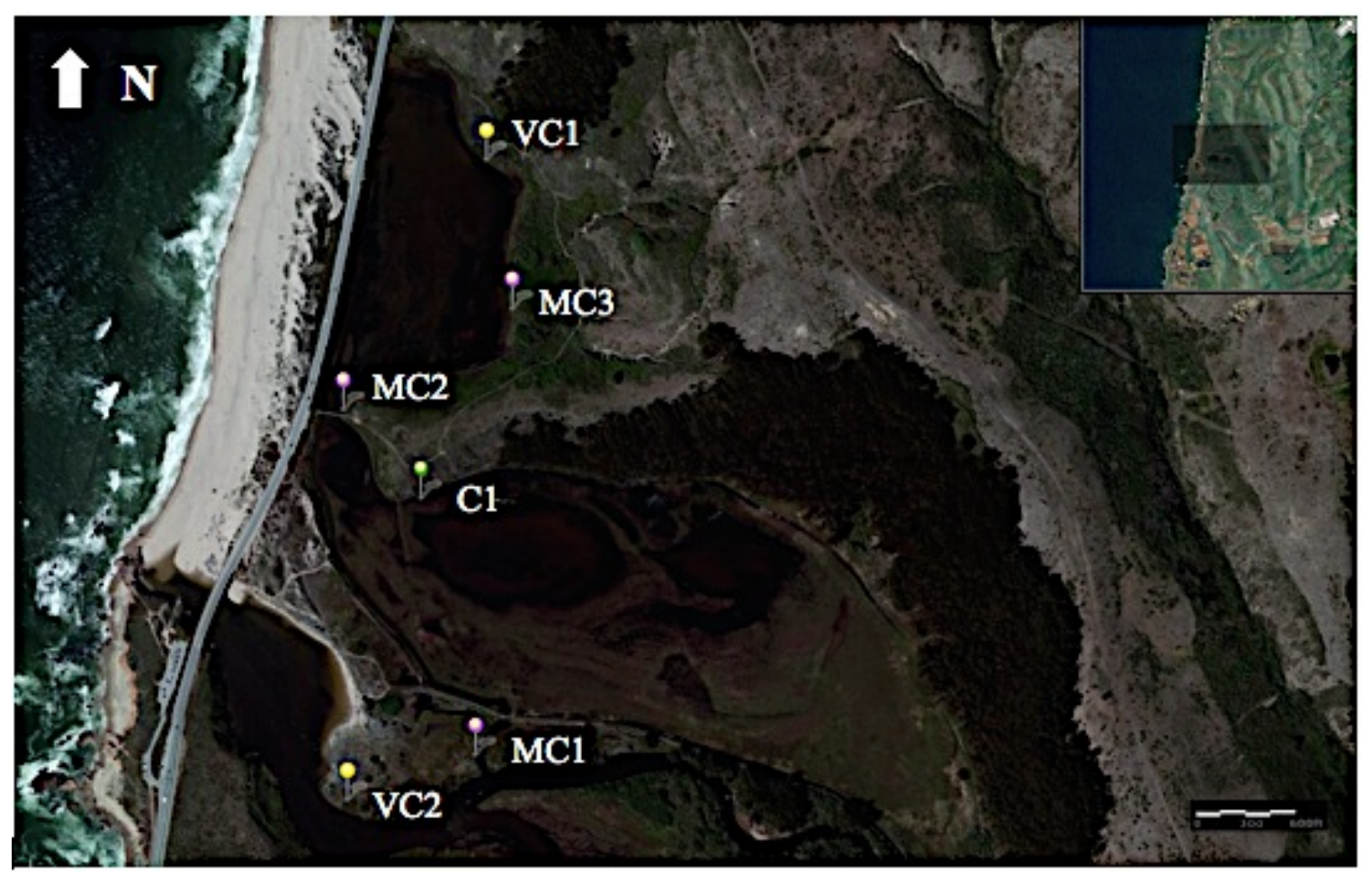

Figure 13: Vibracore (yellow), $30 \mathrm{~cm}$ (green), and $15 \mathrm{~cm}$ (purple) push core locations at Pescadero Lagoon, CA $\left(37^{\circ} 16^{\prime} 01^{\prime}\right.$ ' N, 122 $24^{\circ} 18^{\prime}$ 'W). Data obtained from ESRI, ArcGIS. 2014.

\subsection{Water Quality}

Water samples were collected from various locations within the lagoon, marsh, and the main channel of Pescadero Creek. Based on observational data and preliminary seepage results, the nutrient results within the lagoon were treated as groundwater 
derived nutrients, and the creek was treated as surface water derived nutrients. All water samples collected were analyzed in the lab for nitrate, nitrite, and phosphate. Nutrient concentrations were found by using a color spectrophotometer (Strickland \& Parsons, 1972). In the field, water quality measurements were taken with a handheld YSI, which reports dissolved oxygen, $\mathrm{pH}$, temperature, salinity, specific conductivity, and oxidationreduction potential.

There is a USGS stream gage approximately five miles upstream from the mouth of the estuary, which provides discharge data for Pescadero Creek (National Water Information System, 2013). These data are provided by the USGS and are used to determine the freshwater input into the system (Figure 14).

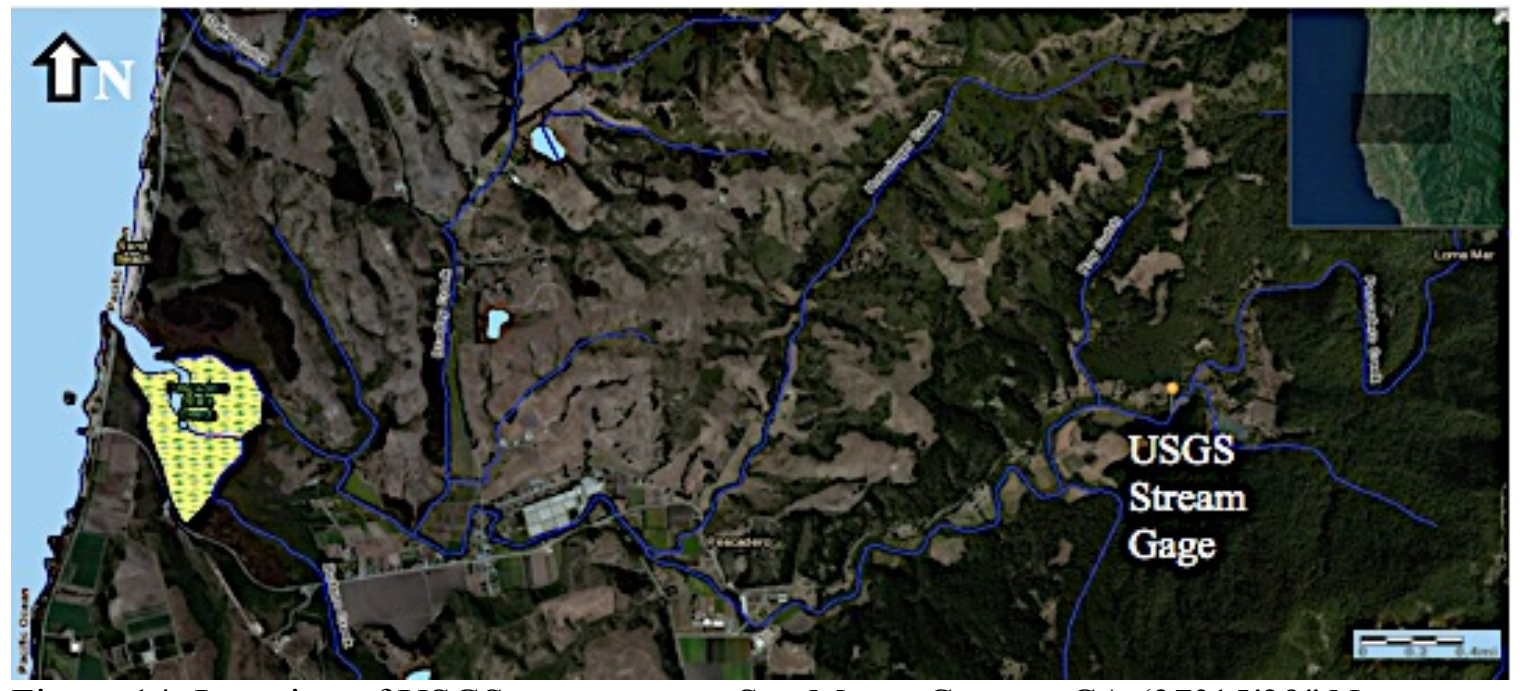

Figure 14: Location of USGS stream gage, San Mateo County, CA $\left(37^{\circ} 15^{\prime} 39^{\prime \prime} \mathrm{N}\right.$, $\left.122^{\circ} 19^{\prime} 40^{\prime \prime} \mathrm{W}\right)$. Data obtained from ESRI, ArcGIS. 2014. 


\subsection{RESULTS}

The combination of geochemical and geophysical techniques were used to quantify groundwater seepage rates, nutrient concentrations and water quality values, and sedimentation rates in the lagoon. From observations and literature research, the following hypotheses were formulated. The first hypothesis is that groundwater seepage values are highest along the northern and eastern slopes of the North Pond compared to other locations. Another hypothesis is that, based on sediment core data, we will see an increase in nutrients and productivity with a decrease in core depth. This is assuming that annual fish kills are directly affected by an increase of nutrients into the system. Since 1995, Pescadero Lagoon has experienced annual fish kills. In 1993, construction was the conducted on Highway 1, which passes over the estuary. The mouth of the estuary changed morphology, which in turn changed the timing of the sand berm formation. In this study, it is under investigation if this action is the reason for sudden fish kills or if there are other contributing factors. With the use of sediment cores a compositional or chemical change should be seen to determine the relation between fish kills and human impacts. A tangential result from collected groundwater seepage data will be to discuss the different methods used objectively. Using heat as a tracer is a fairly novel idea that has not been used widely yet. Being able to compare seepage results from the thermal method and radon detector method will prove to be a notable discussion. Overall, this study seeks to further our understanding of Pescadero Lagoon's dynamics and the detrimental annual fish kills occurring so that an informed decision can be made on how to move forward with remediation efforts. 


\subsection{Groundwater Tracers: Temperature}

Coherence, auto-spectrum, and seepage analyses were done for all seven temperature rods, which cover a time period from March 8, 2013 to February 19, 2014. Figures 15 and 16 show relationships between each sensor and the one directly below it. Sensors 1 to 2 and 2 to 3 show closely correlated temperature overtime with the deeper sensor having lower temperatures than the shallow sensor. The temperature profiles for sensors 3 to 4,4 to 5 , and 5 to 6 show a damped signal; this is true for all temperature rod locations. These data were used to create an auto-spectrum and coherence resulting in a 24-hour phase. The 24-hour cycle was seen more prominent in the shallow sensors and decreased with depth (Figures $17 \& 18$ ). From these analyses, it can be deduced that the farther the temperature rod location is from the estuary mouth, the longer the lag from top to bottom sensor.

The higher the coherence-squared is to one the more prominent that signal is, the coherence-squared decreases with depth indicating that the 24-hour cycle is rarely seen in the deeper sensors. Figure 19 shows a coherence-squared of approximately 0.9 at one cycle per day and Figure 20 shows a coherence-squared of approximately 0.1 at one cycle per day. The coherence decreases significantly with depth, which indicates the temperature signal gets damped quickly. Most of these seepage rate experiments were conducted in streambeds with a higher thermal conductivity, allowing the thermal signal to be transported farther into the sediment. Since the coherence method shows a repeatable signal in the shallower sensors the method developed by Hatch et al. (2006) was used to calculate seepage between the second and third sensors at each location. The 
time series analysis method used suggests that a greater amount of seepage is coming from the North Pond and North Marsh than the main channel of the creek and generally a downward seepage was viewed from all locations. Average seepage rates were calculated for each month showing relatively small seepage rates ranging from $0.2 \mathrm{~m} /$ day upward flow to $-0.3 \mathrm{~m} /$ day downward flow (Figure 21). These results suggest there is no significant groundwater input for 2013 - 2014. Figure 22 shows the annual average seepage at each location. It was expected that the locations in the North Pond would have higher seepage rates than the other locations throughout the lagoon. However the data show that at all locations the annual average was negative indicating a downward flow (e.g., recharge). At location 7 the water is stagnant and blocked by man-made dikes, which is why the data show it as the most negative. Seepage throughout the lagoon plotted for each month shows a maximum seepage rate in June 2013 and minimum seepage rate in January 2014 (Figure 23). Figures 21 to 23 show low or no groundwater flow during this period of time, which correlates with a lack of precipitation during 2013 -2014 . 

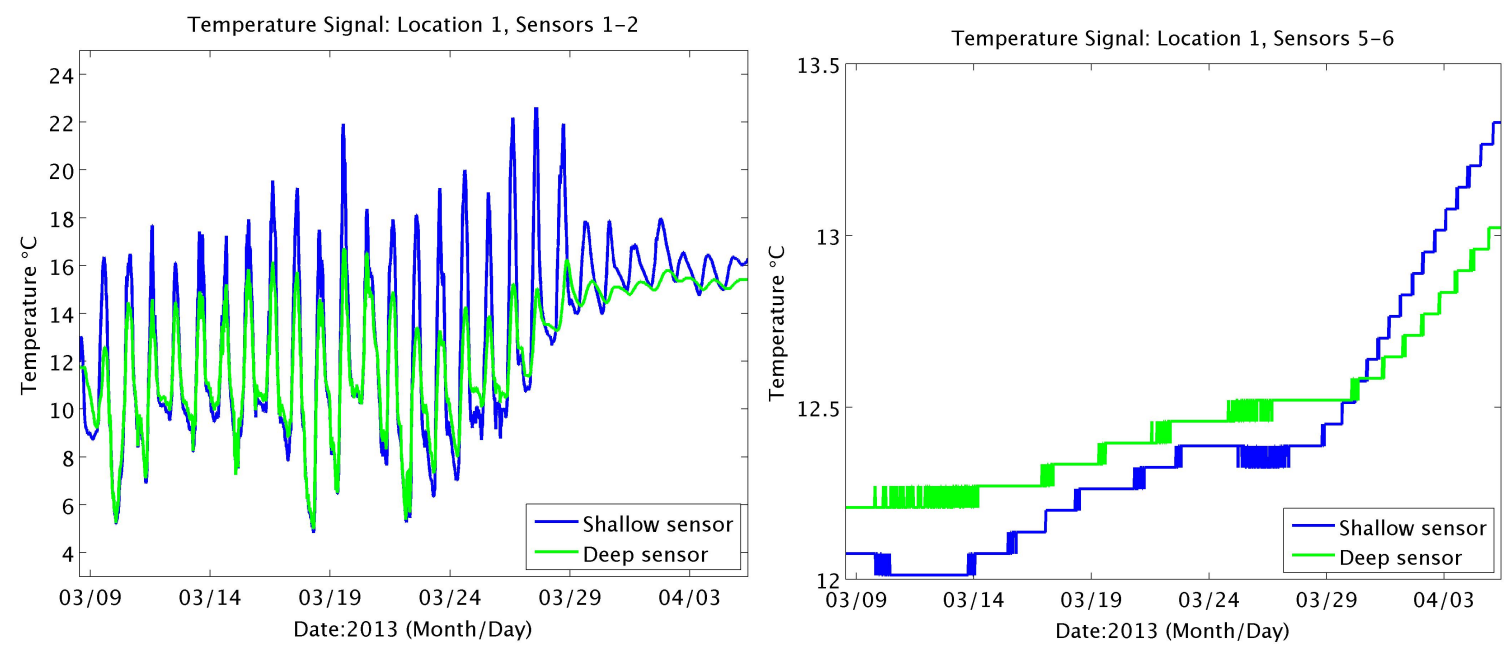

Figures 15 and 16: Temperature variation between sensor depths for temperature rod loaction 1.

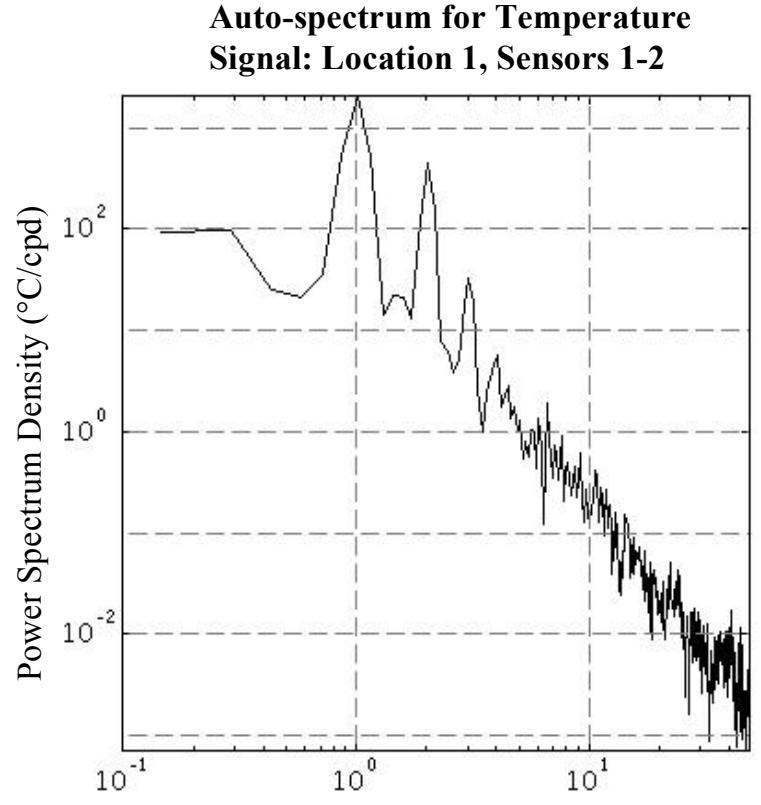

Frequency (Cycles Per Day)

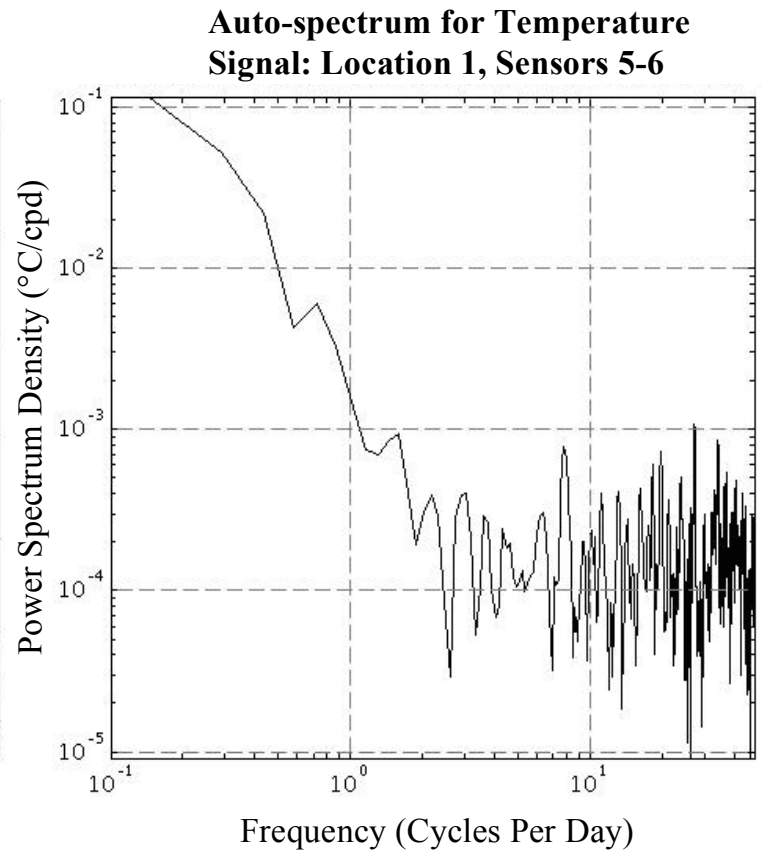

Frequency (Cycles Per Day)

Figures 17 and 18: Auto-spectrum analysis for temperature rod 1, sensors 1 and 2 (left) and 5 and 6 (right). 
Coherence for Temperature Signal: Location 1, Sensors 1-2
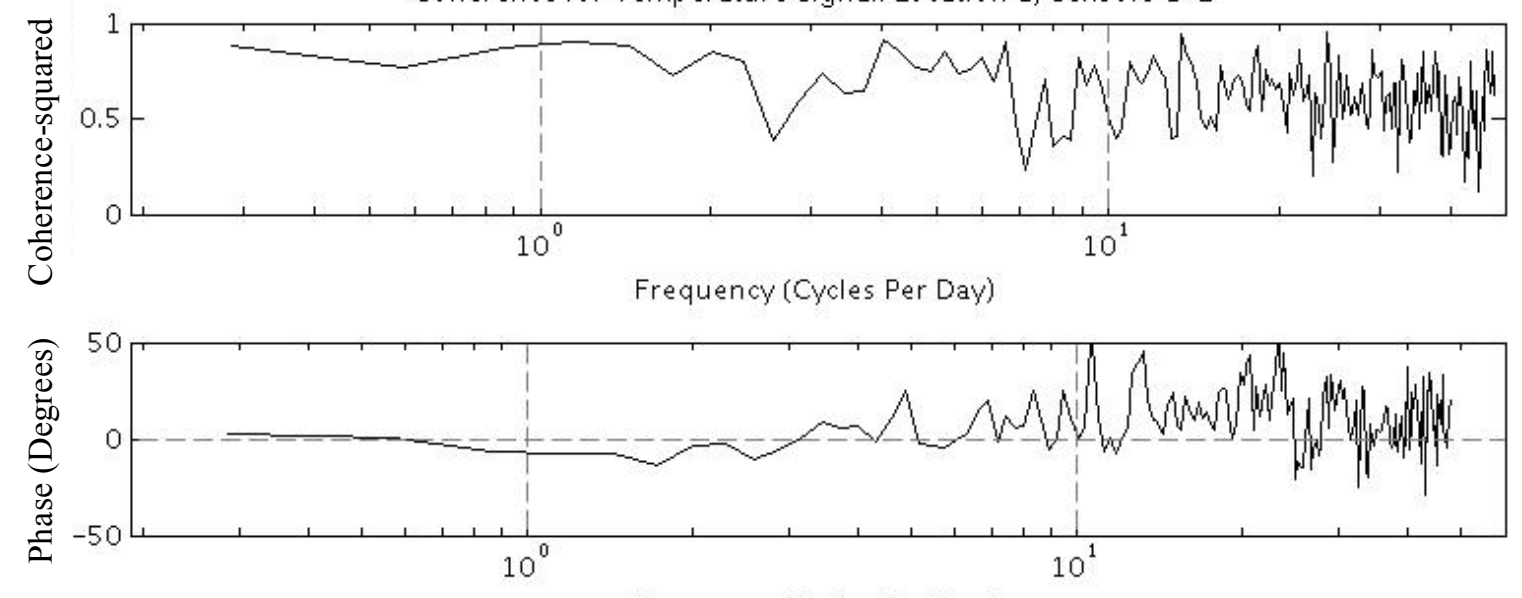

Frequency (Cycles Per Day)

Figure 19: Coherence analysis for temperature rod 1, sensors 1 and 2. At one cycle per day coherence-squared is nearly one.
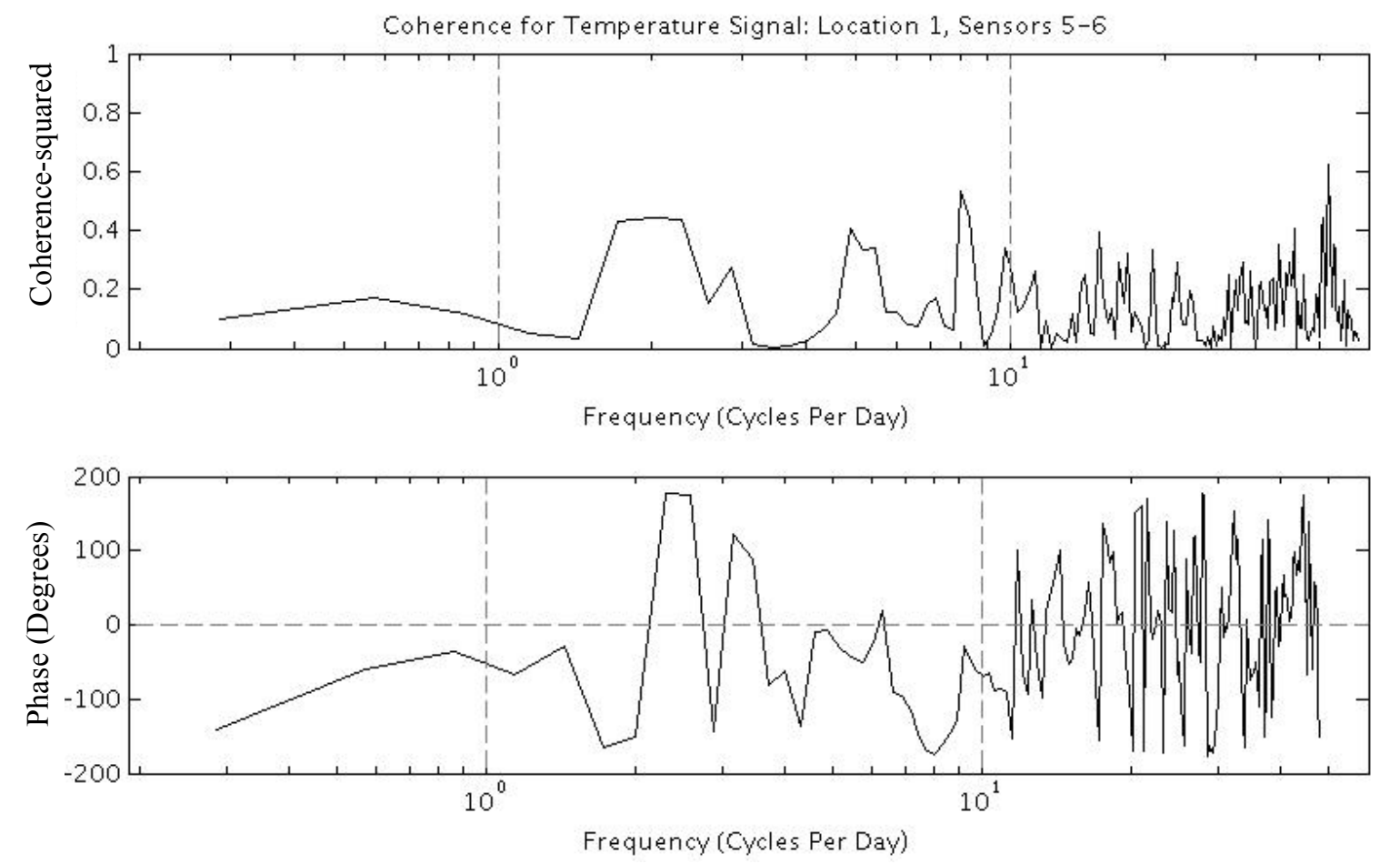

Figure 20: Coherence analysis for temperature rod 1, sensors 5 and 6. At one cycle per day coherence-squared is approximately 0.1 . 


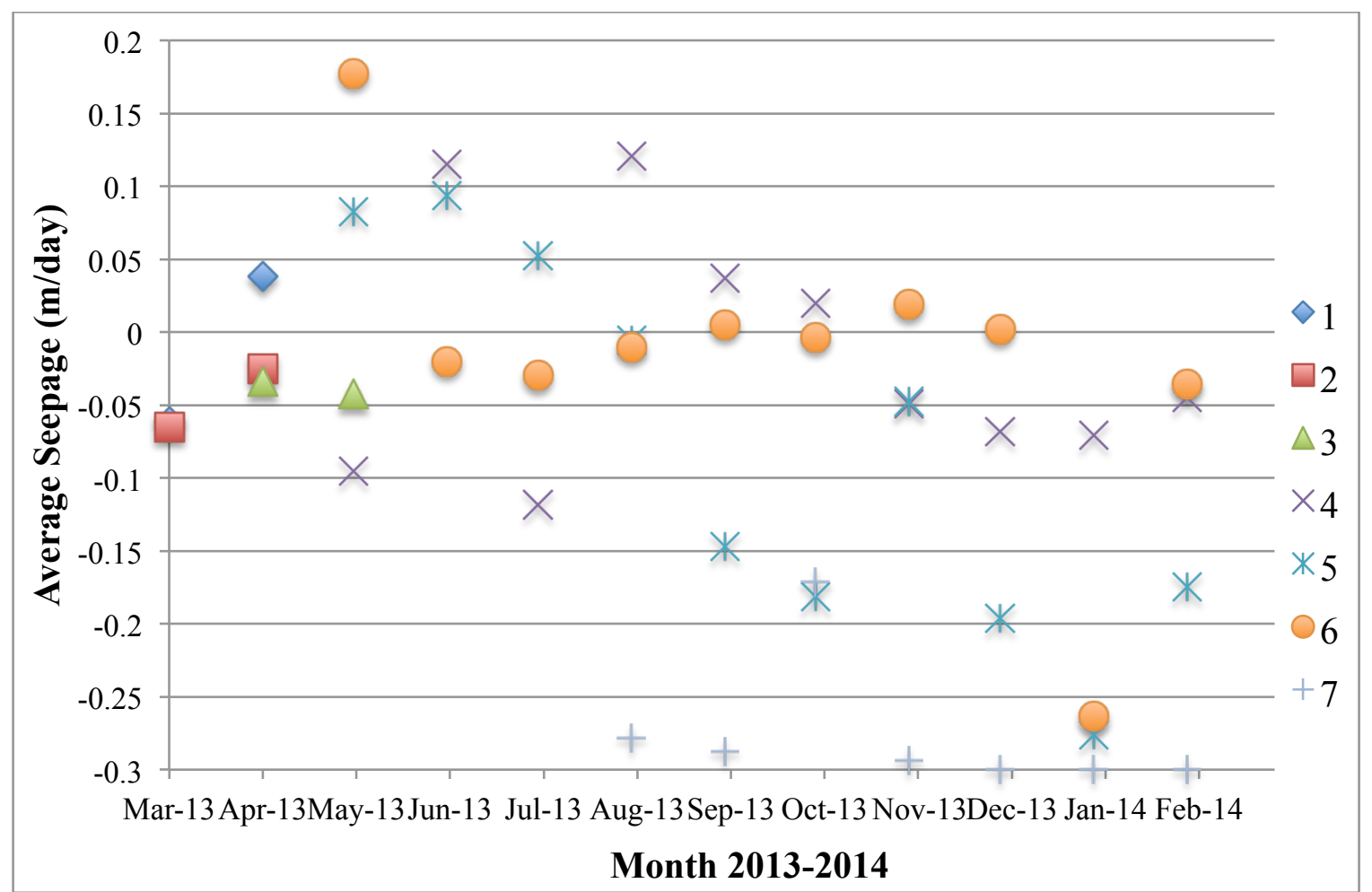

Figure 21: Monthly groundwater seepage in $\mathrm{m} /$ day for seven locations (depicted by different symbols). Negative values indicate recharge or downward flow and positive values indicate discharge or upward flow.

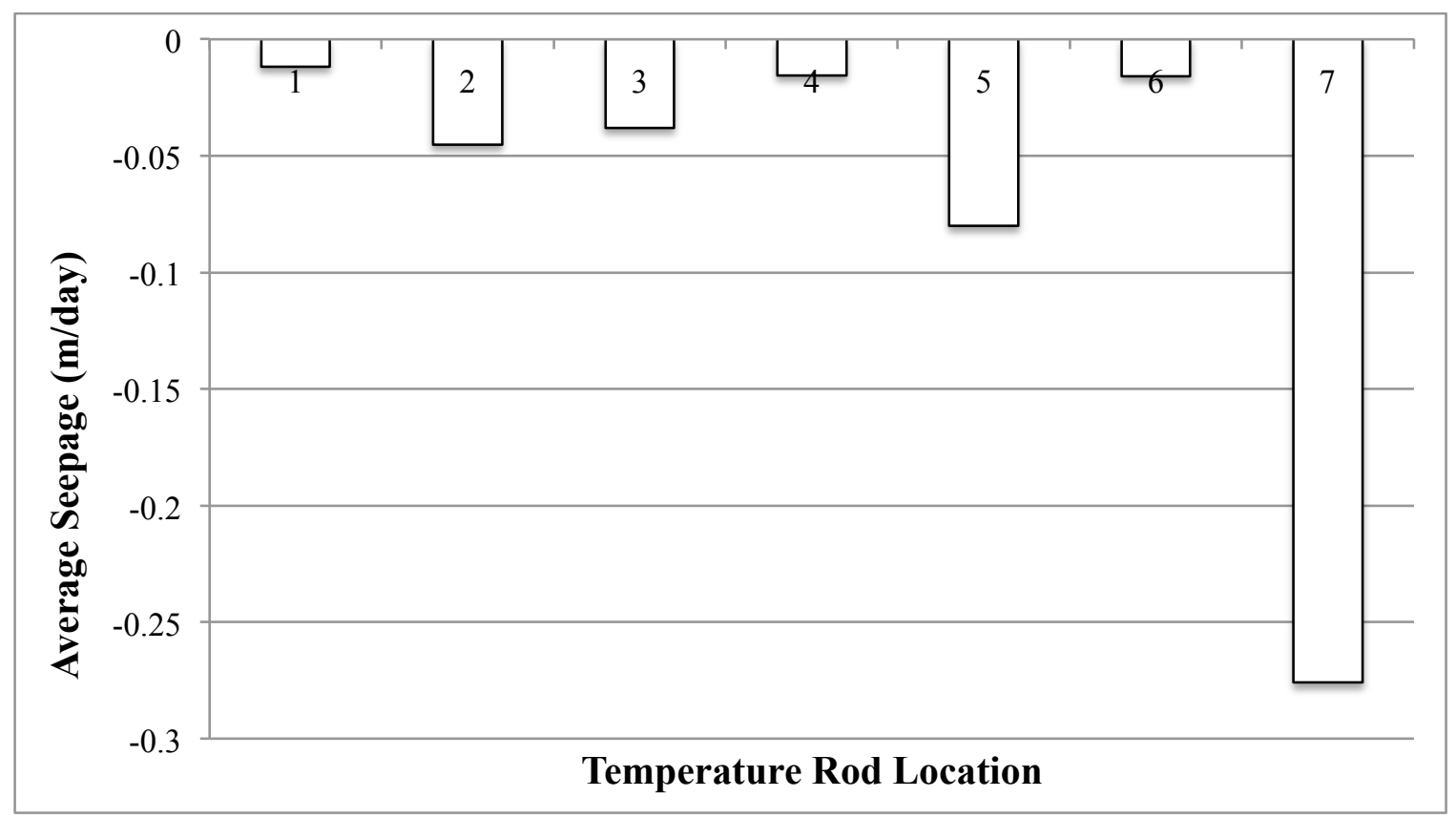

Figure 22: Monthly average groundwater seepage for March 2013 - February 2014 at seven locations. 


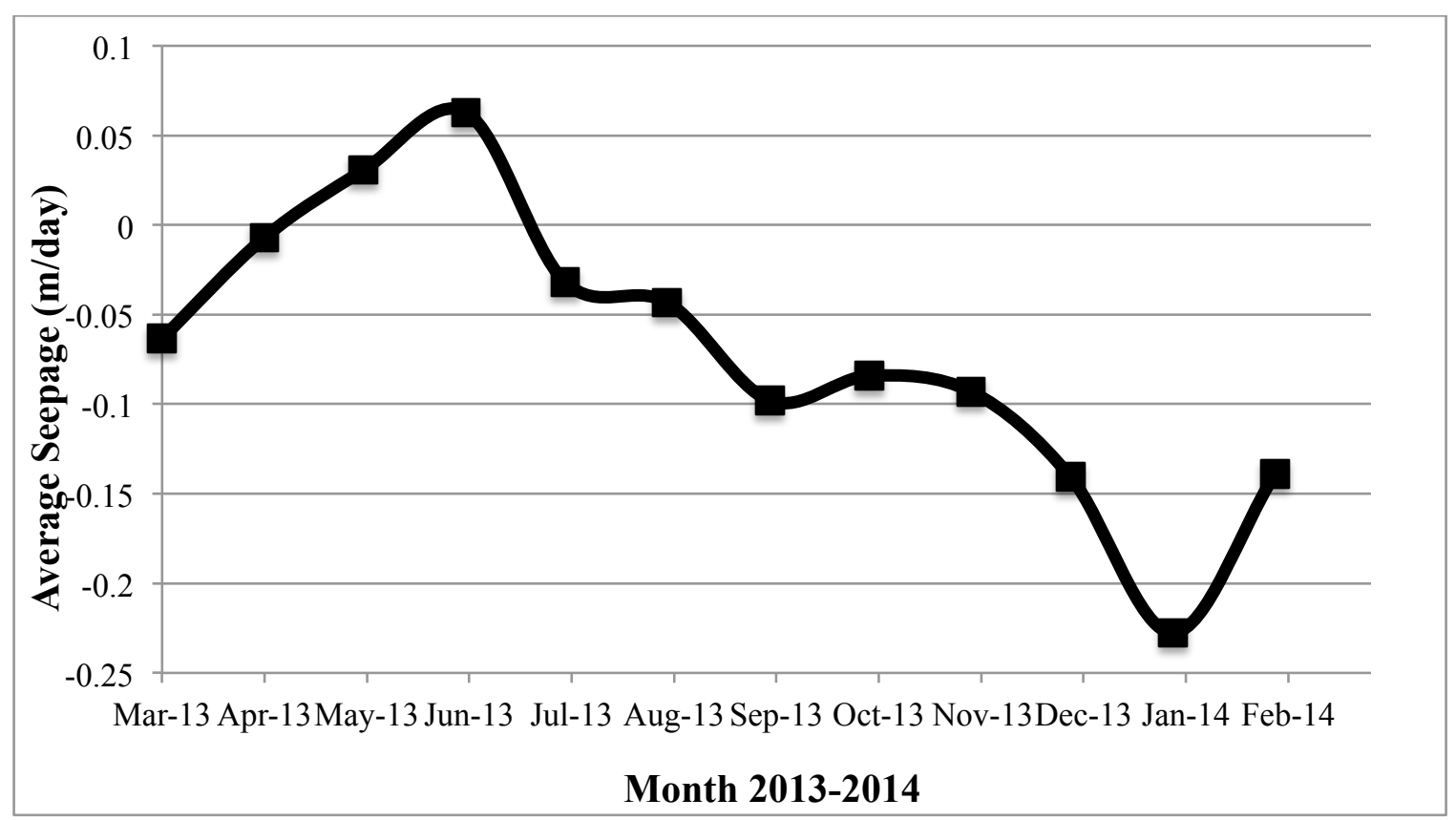

Figure 23: Total monthly average groundwater seepage at all locations across the lagoon.

The sand berm at the mouth of the estuary is typically broken during the winter when wave heights are higher and there is more precipitation. During $2013-2014$, most of central and northern California experienced a drought. Figure 24 compares the low amount of precipitation received in San Mateo County between March 2013 and February 2014 to the normal amounts of precipitation for those months. Precipitation was especially lacking during the winter months of 2013 - 2014. San Mateo County received approximately $64 \%$ less precipitation than normal for the time period displayed. Figures 25 and 26 show surface water discharge into Pescadero Lagoon. Data from 1951 - 2013 show no significant pattern over time to rates entering the lagoon. Figure 26 shows rates below $0.3 \mathrm{~m}^{3} / \mathrm{s}$ from June - November in all years, which is usually the dry season. The December - May months vary from year to year. Both in 1990 and 2013 the 
entire year did not see rates above $1 \mathrm{~m}^{3} / \mathrm{s}$, but the difference in those year is that in 1990 there was no fish kill recorded and there was in 2013. Winter storms along the coast are characterized by increased wave heights. On average, December to March show wave heights of approximately $2.5 \mathrm{~m}$ (Figure 27). The combination of increased precipitation and wave height generally keeps the mouth open during the winter months.

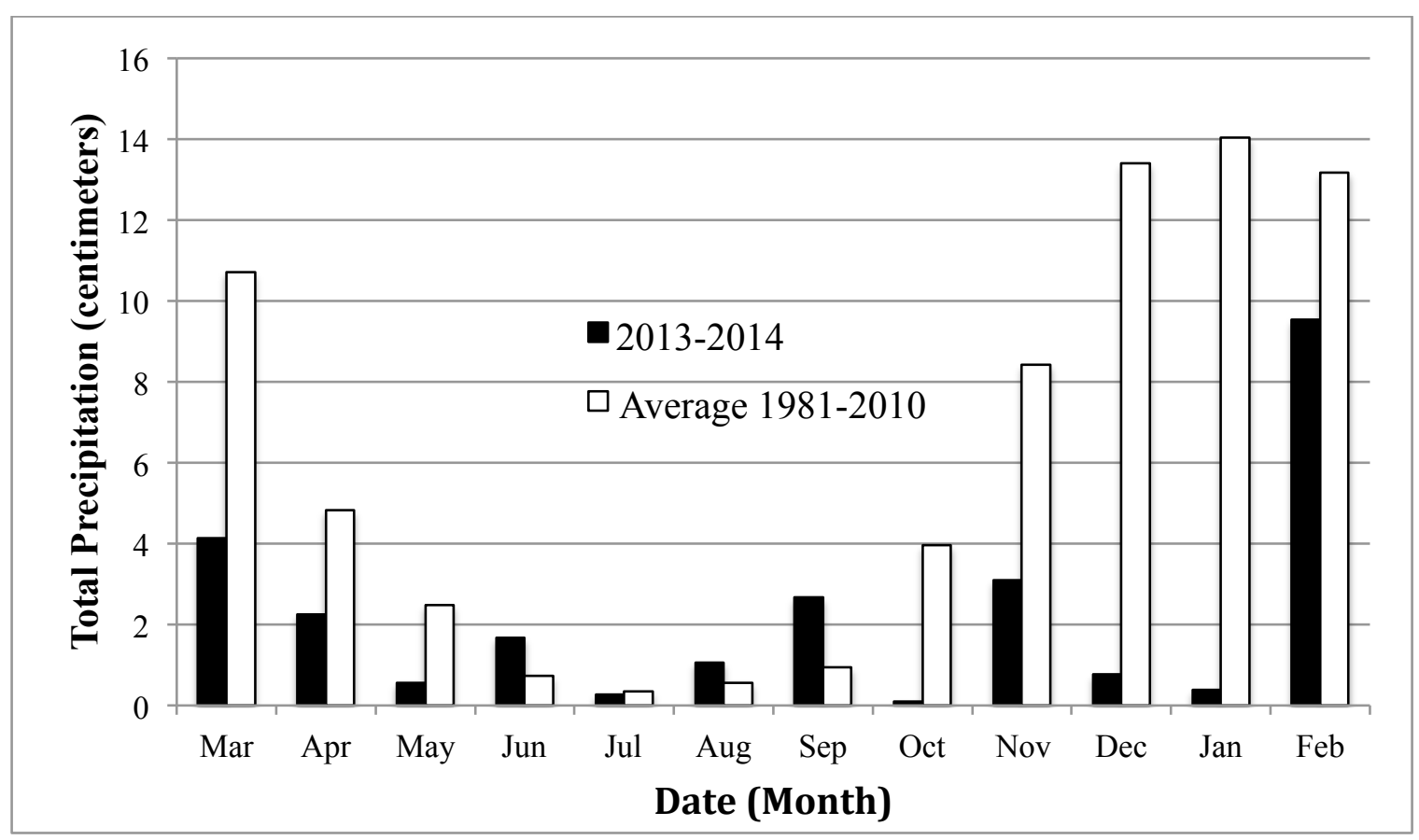

Figure 24: Total monthly precipitation for San Mateo County for 2013-2014 and monthly average for 1981-2010. Data obtained from "Monthly Summaries of Global Historical Climatology Network, San Mateo County, CA," by the National Oceanographic and Atmospheric Administration, Climate Data Online. 2013. 


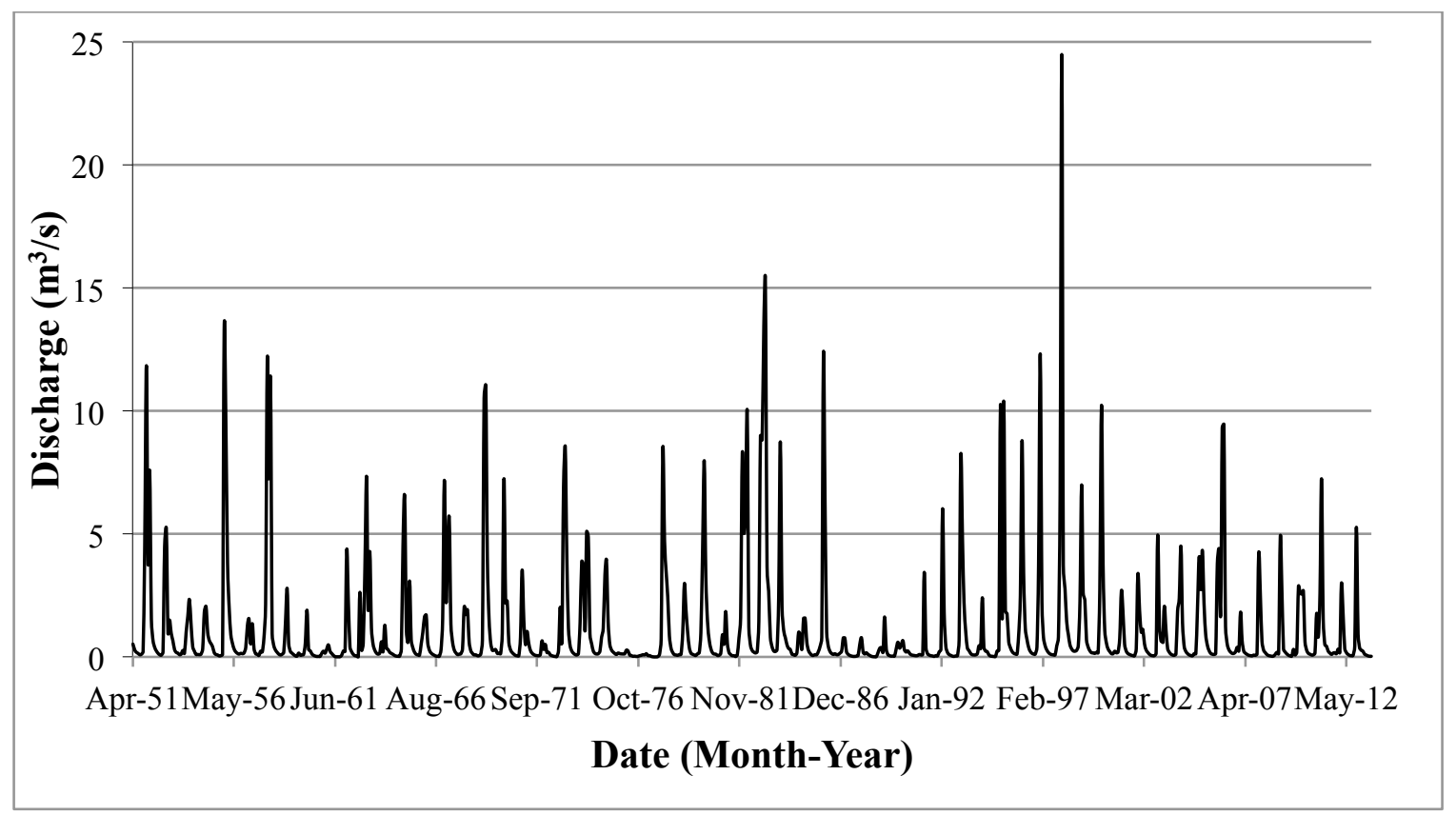

Figure 25: Monthly average surface water discharge - Pescadero Creek $1951-2013$. Data sourced from "USGS 11162500 Pescadero C NR Pescadero CA," by the United States Geological Survey's National Water Information System. 2013.

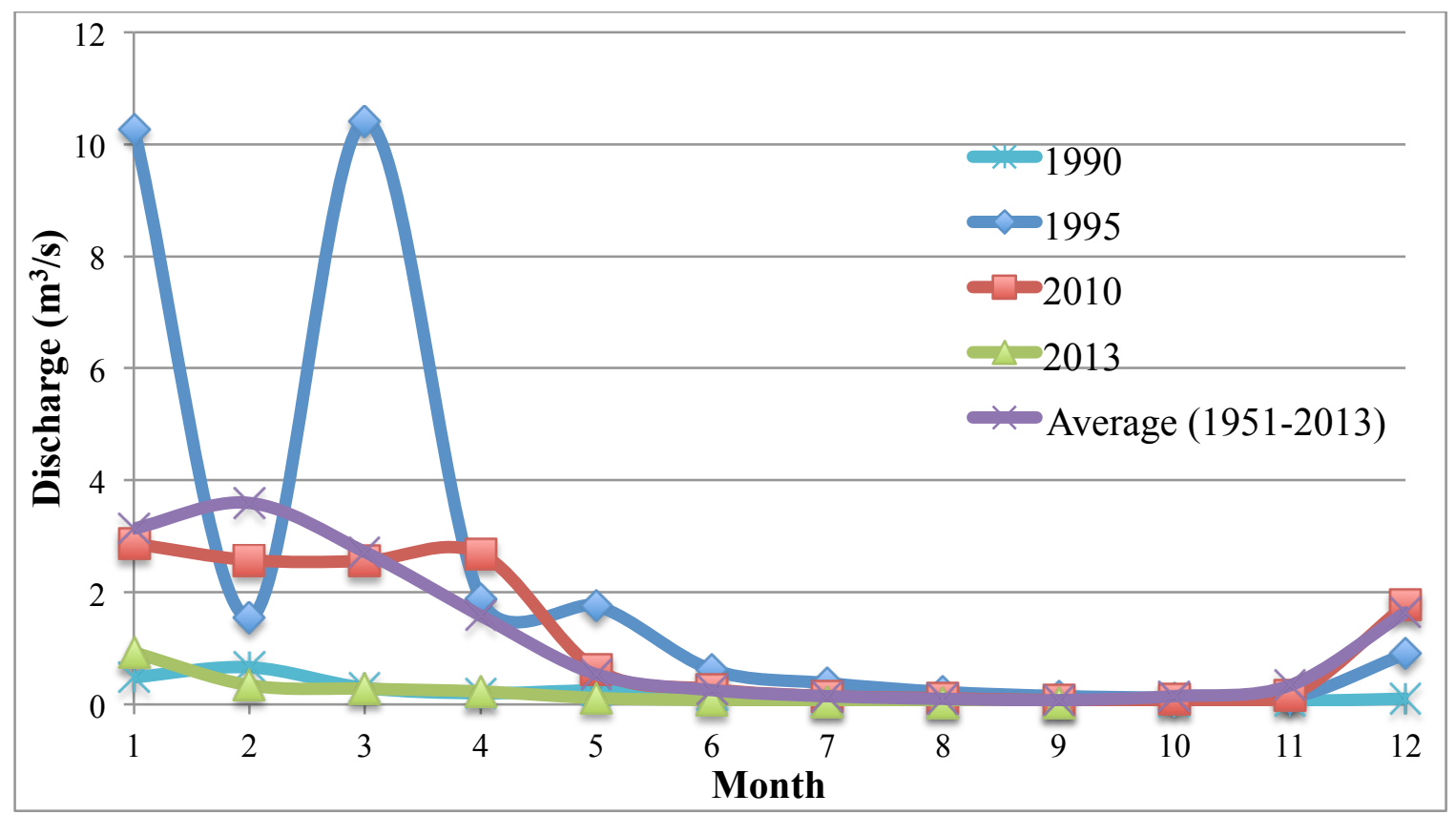

Figure 26: Monthly average surface water discharge - Pescadero Creek for 1990, 1995, 2010, 2013, and an average from 1951 - 2013. Data sourced from "USGS 11162500 Pescadero C NR Pescadero CA,” by the United States Geological Survey's National Water Information System. 2013. 


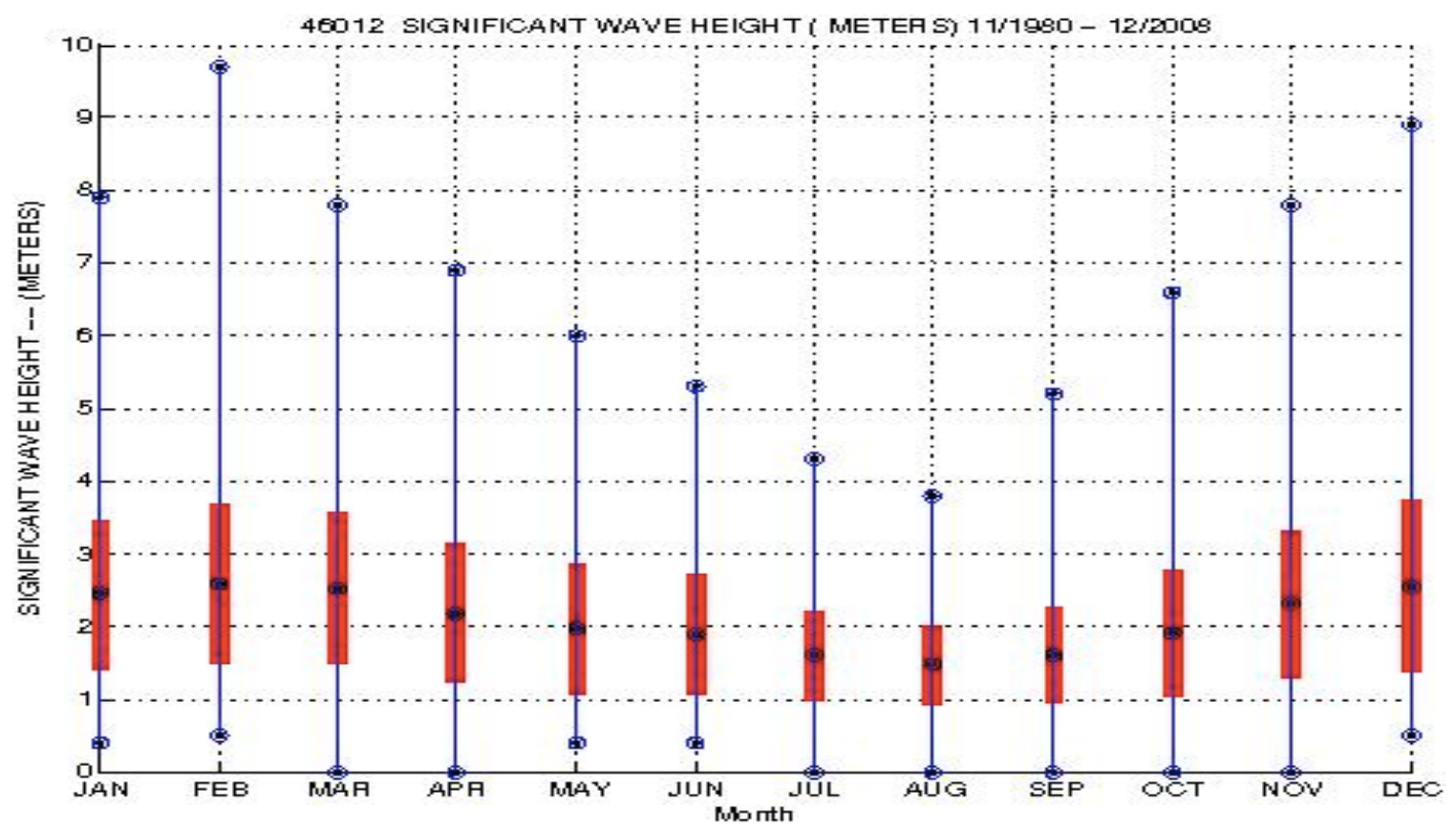

Figure 27: Significant wave height near Half Moon Bay ( $37^{\circ} 21^{\prime} 47^{\prime \prime}$ N, $122^{\circ} 52^{\prime} 52^{\prime \prime}$ W). Adapted from "Station 46012 (LLNR 325) - HALF MOON BAY - 24NM SSW of San Francisco, CA," by National Oceanic and Atmospheric Administration's National Buoy Data Center. 2014.

\subsection{Groundwater Tracers: Radon}

The radon method confirms the lack of groundwater flow results from the temperature method. The measurement of radon in the atmosphere, surface water measurements, is compared to groundwater measurements to calculate a seepage rate. From nearly two days of radon measurement in the groundwater a submarine groundwater discharge rate of $0.001 \mathrm{~m} /$ day was found (Figure 28). This finding supports the conclusion that during $2013-2014$ there was an insignificant groundwater input. 


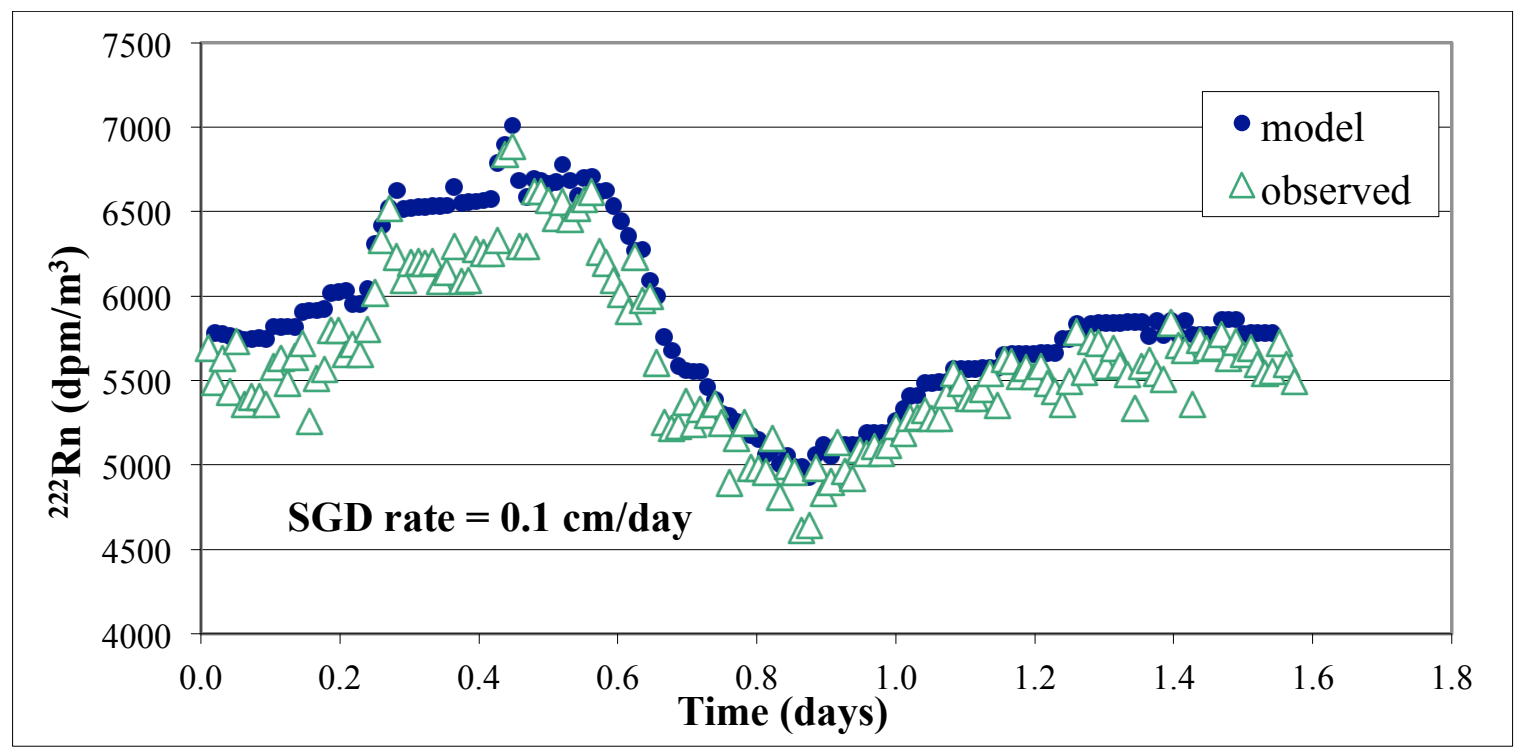

Figure 28: Radon-222 (disintegrations per minute, dpm) activities measured in the groundwater at Pescadero Lagoon. Submarine groundwater discharge was calculated to be $0.1 \mathrm{~cm} /$ day.

\subsection{Groundwater Tracers: Electrical Resistivity}

Multiple electrical resistivity surveys were conducted on Pescadero State Beach near the mouth of the estuary (Figure 12). The first surveys were conducted in March when the water had surficial access the ocean and the second set of surveys were conducted in August when the sand berm had closed and there was no surficial exchange. Both set of surveys were conducted at low tide so the seawater interference would be minimal from the west. In August groundwater seepage could be visually seen to the south of A3 line and west of A2 line. The mouth of the estuary is bound to the south by a rock outcrop and based on the visual groundwater seepage observation and confirmation from the resistivity images the preferential flow path stays close to the outcrop. The resistivity images are a visual interpretation of an underground image. The conductivity differences in the subsurface can be imaged into color changes where high 
conductivity and low resistivity are represented by cooler colors and low conductivity and high resistivity are represented by warmer colors. Seawater has a higher conductivity than freshwater and conductivity is the reciprocal of resistivity (Figure 29). Figure 30 and 31 were taken in similar locations and show little groundwater flow. Figure 32 was taken parallel to shore and shows a freshwater flux along the south end, closest to the rock outcrop. Figure 33 intersects with the parallel line. The highest elevation point for this line is at electrode 19, where there is a high resistivity band. This most likely indicates dry sand, which would have a low conductivity. Also in this image there appears to be a layer of seawater between a depth of 5 to $8 \mathrm{~m}$ and an overlying freshwater layer.

\section{Electrical Conductivity in $\mathrm{S} / \mathrm{m}$}

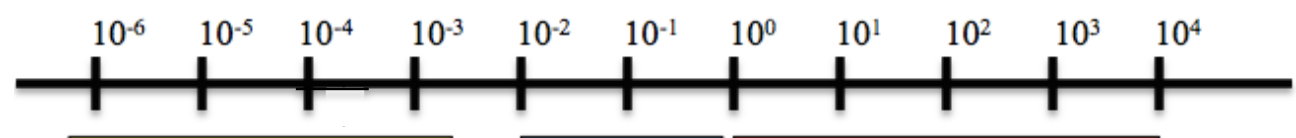

\section{Igneous Rocks}

Freshwater

Ore Minerals

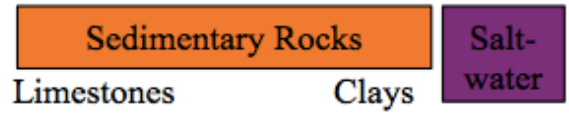

Graphite

Figure 29: Typical electrical conductivity of rocks, minerals, and fluids. Conductivity is the reciprocal of resistivity.

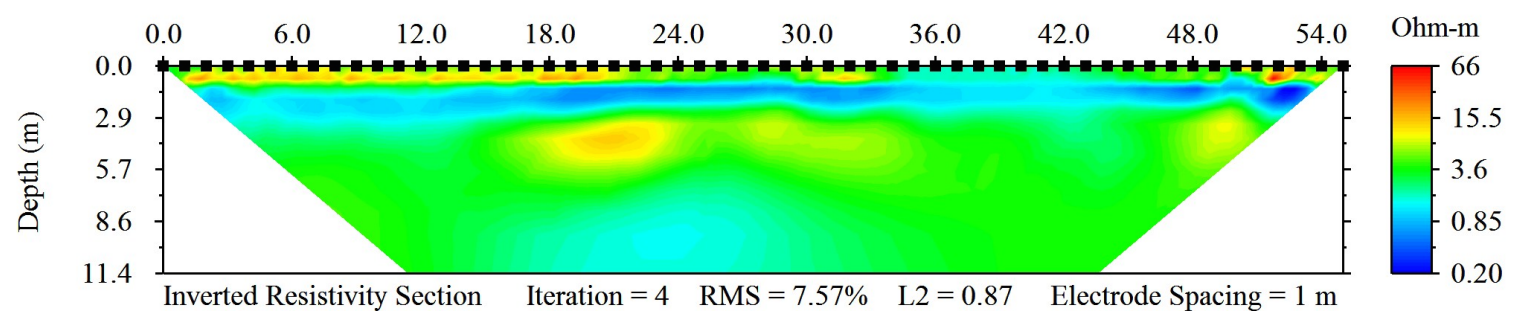

Figure 30: M1-Perpendicular to shore, 14:50 March 8, 2013, 0 to $54(\mathrm{E}-\mathrm{W})$. The $\mathrm{x}$-axis is measured in electrodes, where each electrode is spaced one meter apart ( 0 is the starting location). The color bar is measured in ohm-m, which is a measurement of resistivity per distance. 


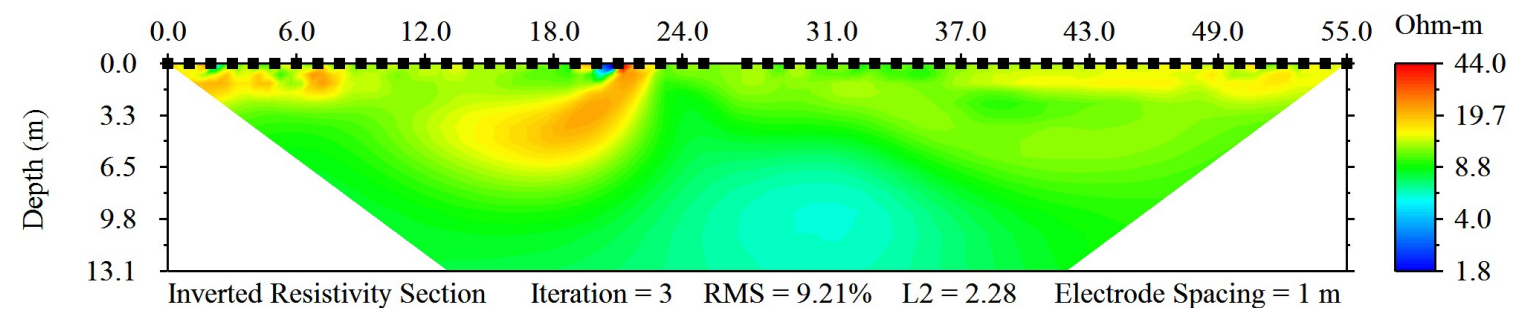

Figure 31: A1-Perpendicular to shore, 10:00 August 13, 2013, 0 to $55(\mathrm{E}-\mathrm{W})$. The $\mathrm{x}$-axis is measured in electrodes, where each electrode is spaced one meter apart ( 0 is the starting location). The color bar is measured in ohm-m, which is a measurement of resistivity per distance.

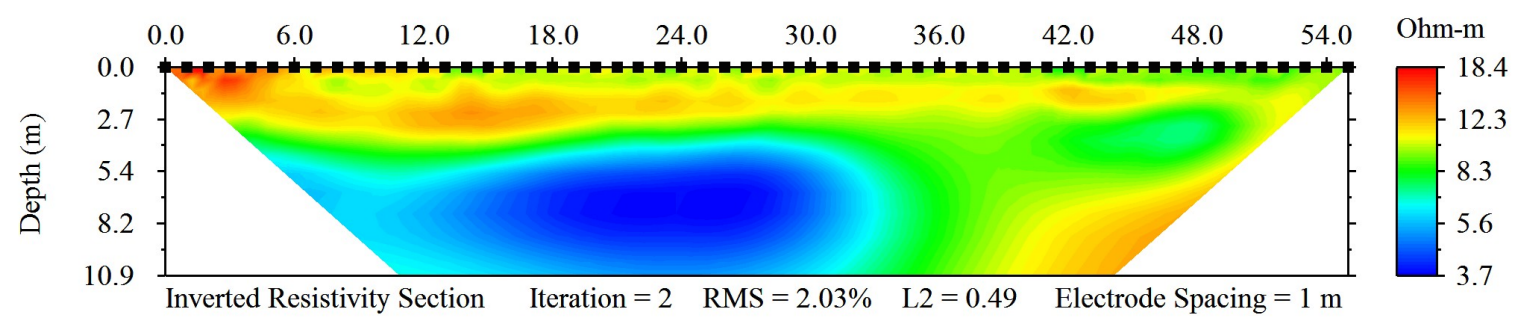

Figure 32: A2-Parallel to shore, 11:00 August 13, 2013, 0 to $54(\mathrm{~N}-\mathrm{S})$. The $\mathrm{x}$-axis is measured in electrodes, where each electrode is spaced one meter apart ( 0 is the starting location). The color bar is measured in ohm-m, which is a measurement of resistivity per distance.

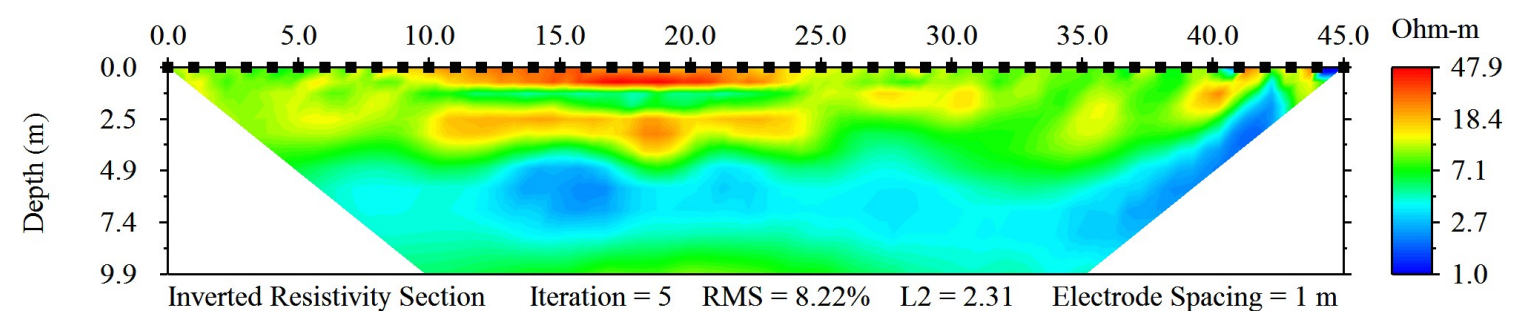

Figure 33: A3-Perpendicular to shore, 13:00 August 13, 2013, 0 to $54(\mathrm{E}-\mathrm{W})$. The $\mathrm{x}$-axis is measured in electrodes, where each electrode is spaced one meter apart $(0$ is the starting location). The color bar is measured in ohm-m, which is a measurement of resistivity per distance.

\subsection{Geochronology}

The sediment core recovered from Pescadero Lagoon on June 7, 2013 was analyzed for excess $\mathrm{Pb}-210$ isotopes to determine sedimentation rates and relative ages associated with core depth. Carbon and nitrogen percentages were found for every one $\mathrm{cm}$, down to a total depth on $27 \mathrm{~cm}$. Carbon percentages ranged from $0.71 \%$ to $6.3 \%$ and 
nitrogen percentages ranged from $0.07 \%$ to $0.67 \%$. Both nitrogen and carbon profiles show similar trends with depth (Figures 34 and 35).

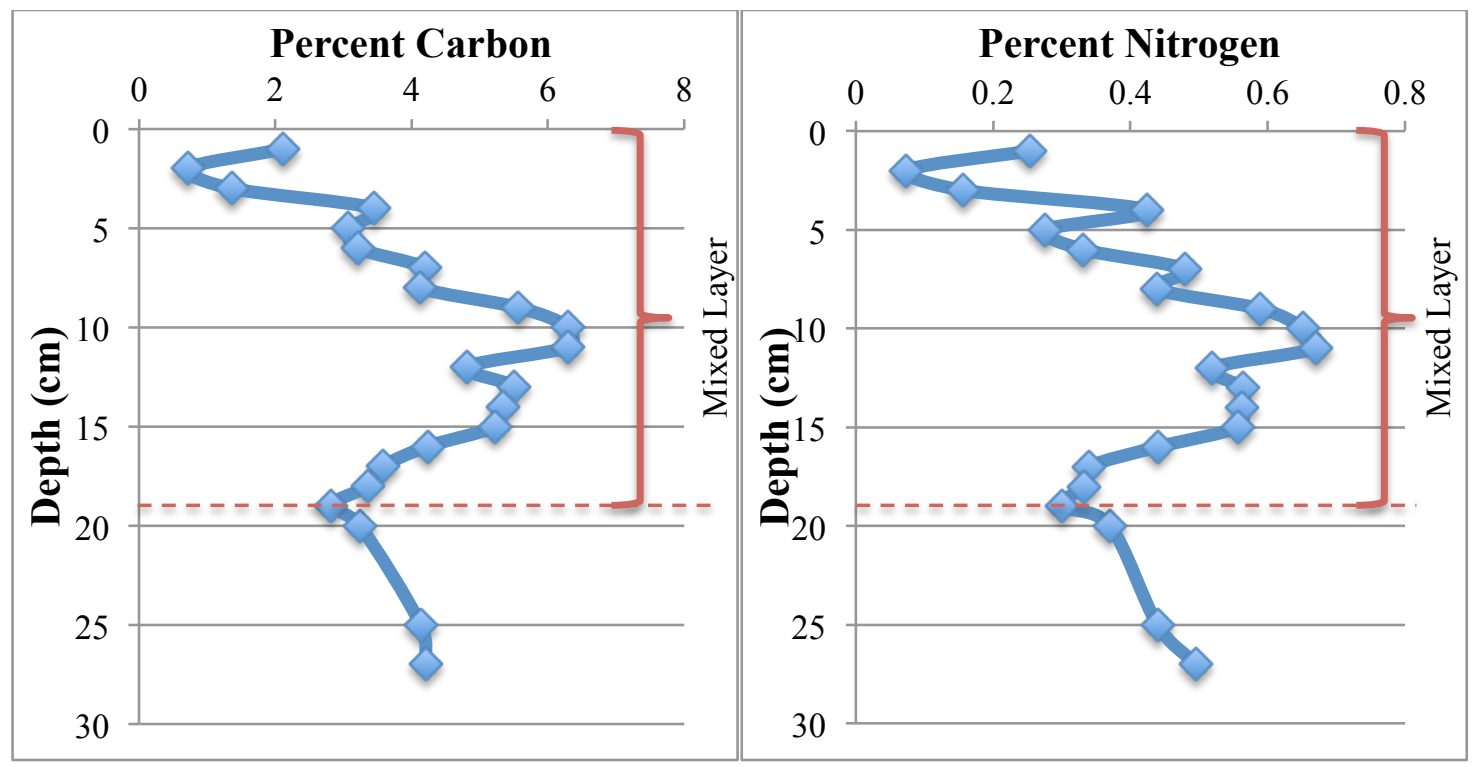

Figures 34 and 35: Carbon and nitrogen percentages with depth in sediment core C1.

Based on the $\mathrm{Pb}-210$ profile, the sediment column appears to be well mixed to a depth of $\sim 17.5 \mathrm{~cm}$. A linear sedimentation rate below the mixed layer is calculated to be $0.15 \mathrm{~cm} /$ year from Cs-137 activities (Figure 36). Based on excess Pb-120 activities the linear sedimentation rate estimated to be $0.19 \mathrm{~cm} / \mathrm{year}$ and a mass accumulation rate of $86.23 \mathrm{mg} / \mathrm{cm}^{2} /$ year (Figures 37 and 38). The carbon, nitrogen, cesium, and lead profiles all show a relatively deep mixed layer and after a depth of $17.5 \mathrm{~cm}$ show a linear relationship. The deep mixed layer most likely signifies a seasonal drying and refilling in of water in the marsh, which would disturb the top layer of sediment. From both the cesium and lead profiles a sedimentation rate of 0.15 to $0.19 \mathrm{~cm} / \mathrm{year}$ can be assumed. 


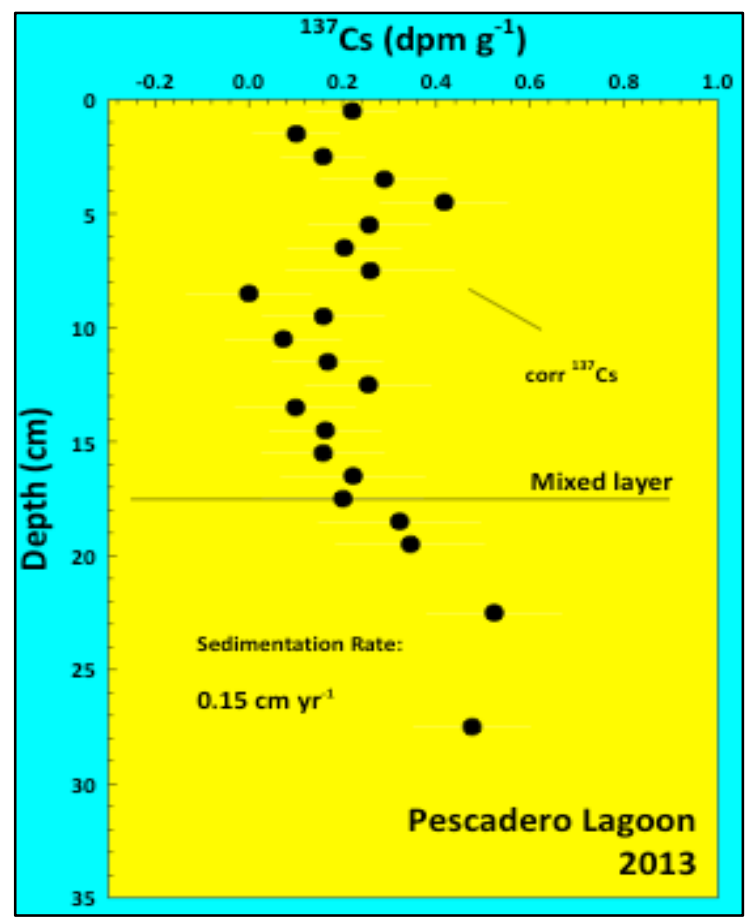

Figure 36: Cesium-137 activities $(\mathrm{dpm} / \mathrm{g})$ with depth $(\mathrm{cm})$ in $\mathrm{C} 1$. Showing sedimentation rate of $0.15 \mathrm{~cm} /$ year.
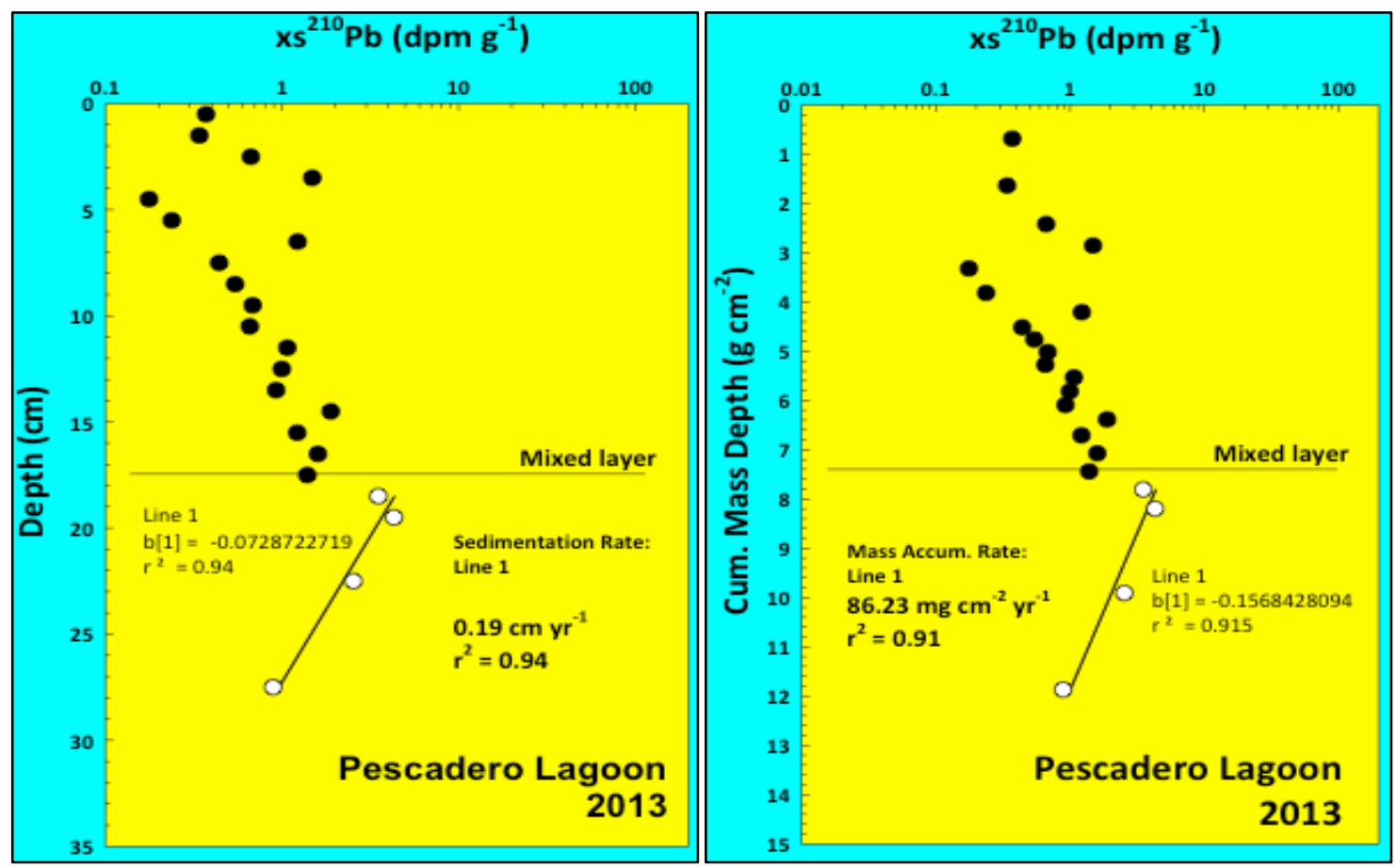

Figures 37 and 38: Lead-210 activities $(\mathrm{dpm} / \mathrm{g})$ with core depth $(\mathrm{cm})$ in C1. Showing a linear sedimentation rate of $0.19 \mathrm{~cm} /$ year and mass accumulation rate of 86.23 $\mathrm{mg} / \mathrm{cm}^{2} /$ year. 
From analyzing the sediment data collected some comparisons between cores can be made. Core logging shows the major lithology of $\mathrm{VC} 1$ as silt and the minor as clay and VC2 has a major lithology of sand and the minor as gravel. This observational method was further proved with the laser particle size (LPS) analysis quantitatively showing silt and clay as the major and minor lithologies. LPS analysis shows sand as the major lithology for VC2; the LPS analyzer is not capable of measuring gravel. LPS analysis was also used for MC1 and MC3, showing silt as the dominant component. Further analysis of VC1 and VC2 were done my using smear slide counts to determine the composition of the material. Both cores showed a fairly similar composition with high percentages of silicicalstics, opaques, and clay. Small amounts of diatoms and sponge spicules were found. With SEM and EDX work large amounts of diatoms, framboidal pyrite, and clay were viewed in C1. SEM images show some of the diatoms were replaced by pyrite framoids and an EDX analysis was done to confirm that the composition is in fact $\mathrm{FeS}_{2}$.

\subsection{Water Quality}

Nutrient analysis were conducted on 40 water samples collected between August 15, 2013 and October 22, 2013 at various locations throughout the lagoon, the results are plotted in Figure 39. The average concentrations for nitrate, nitrite, and phosphate are 4.30 micromolar $(\mu \mathrm{M}), 0.75 \mu \mathrm{M}$, and $6.04 \mu \mathrm{M}$, respectively. Surface water and groundwater time series samples as well as surface water grab samples from various locations are incorporated into Figure 38. 


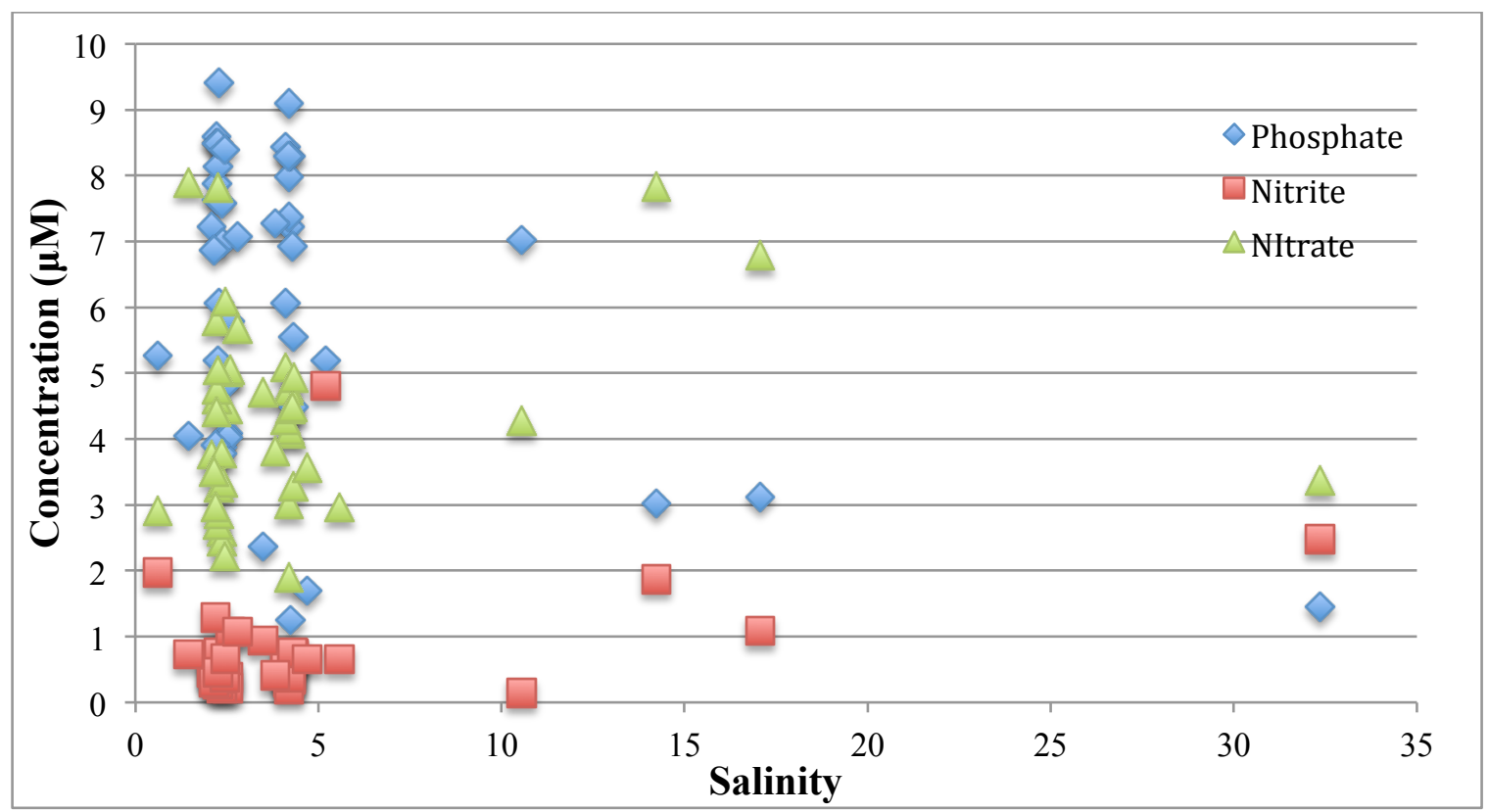

Figure 39: Nutrient concentrations of phosphate, nitrate, and nitrite in water samples from Pescadero Lagoon.

\subsection{DISCUSSION AND CONCLUSION}

The purpose of the study was to identify and quantify the groundwater discharge and associated nutrient inputs for Pescadero Lagoon, CA. Various geochemical and geophysical methods were used to achieve this.

Estuarine systems are constantly changing, complex systems that play a crucial role in the environment. Many marine and terrestrial animals rely on this type of ecosystem to survive. Over the past decade California has lost $91 \%$ of its wetlands and $83 \%$ of the total miles of California's rivers and streams are impaired (Van Nostrand \& Reinholdt, 1993). Some of the main reasons for impairment are due to hydrologic alteration, pollution inputs, and vegetation damage.

One of the main ecological concerns within Pescadero Lagoon is the death of steelhead trout. Steelhead trout use the lagoon for spawning during the early stages of 
their life cycle and then return to the ocean in adulthood. These fish require welloxygenated waters and are sensitive to temperature change (NOAA Fisheries West Coast Region, 2013). Pescadero Lagoon was a well-suited habitat for fish and other inhabitants, until recently. Over the past decade, fish kill events have concerned scientists and the community.

Seasonally, a sand berm will form at the mouth of the estuary when freshwater input and wave height are low. This blocks direct access to the ocean. Circulation within the lagoon declines creating a heavily stratified water column with a colder low oxygen layer sitting near the bottom. When the sand berm eventually breaks, water circulation is intensified; the turbulent mixing of oxygen-depleted water and the addition of hydrogen sulfide can suffocate the fish in the lagoon.

\subsection{Contaminants}

The EPA sets regulations for the maximum contaminant level (MCL) allowable for a certain substance in drinking water. The MCL for nitrate-N and nitrite-N are 10 milligram per liter $(\mathrm{mg} / \mathrm{L})(710 \mu \mathrm{M})$ and $1 \mathrm{mg} / \mathrm{L}(71 \mu \mathrm{M})$, respectively. High levels of nitrate and nitrite are typically found in agricultural runoff because they are used in fertilizers. For example, Elkhorn Slough, a larger estuary approximately $80 \mathrm{~km}$ southeast of Pescadero has exceeded nitrate concentrations of $1000 \mu \mathrm{M}$ (Novak, 2011). The range for nitrate concentrations in Elkhorn Slough range from $<1$ to $>2000 \mu \mathrm{M}$, higher concentrations are typically detected after a rain event (Jannasch et al, 2008). Pescadero Lagoon and Creek are surrounded by agriculture so a high concentration of nutrients 
would be expected in the water. However, we found values significantly lower than the EPA drinking water standards. Nutrient concentrations are lower than expected. All water samples were collected during a time with no recent precipitation. Since Elkhorn Slough sees a spike in nutrient concentrations after a rain event, samples should have been taken after a rain event to compare with samples during a dry period. Nutrient concentrations are typically higher after a rainfall event due to increased agricultural rainfall.

Another possible explanation for the small nutrient concentrations is that nitrate is quickly reduced to sulfate (Figure 40). Nitrogen in the system could be more abundant in the oxygen reduced ammonium form rather than the oxygenated nitrate or nitrite form. This is plausible because of the abundant evidence of organic matter and framboidal pyrite in the sediment (Figure 41). The formation of pyrite $\left(\mathrm{FeS}_{2}\right)$ comes by way of sulfate reducing bacteria, which are found in anoxic zones, sulfate is reduced after oxygen and nitrogen have already been reduced (Wilkin \& Barnes, 1996). Sulfide is produced in warm, high-productivity, saline waters much like Pescadero Lagoon (Reese, Anderson, \& Amrhein, 2008). The Salton Sea and Pescadero Lagoon suffer a similar fate. Both have high algal producitivity, warm water, and as a result produce sulfide. The Salton Sea suffers from fish kills in the summer when strong winds in July mix the low oxygen water and hydrogen sulfide into the surface water (Reese et al, 2008). The mixing mechanisms and timing of fish kills are different for both water bodies but both share the same processes.

The resultant framoidal pyrite left in the sediment column is evidence of 
eutrophication and hydrogen sulfide production. In marine and lacustrine systems pyrite is the most common authigenic sulfide mineral found in the sediment (Neumann, 2005). A study by Bush, Sullivan, Bush, and Ward (2006) has shown that presence of pyrite in the sediment record can suggest when an estuary was closed or open to the ocean. Pyrite formation relies on the availability of sulfur; light sulfur $\left({ }^{32} \mathrm{~S}\right)$ is preferred to the heavier sulfur $\left({ }^{34} \mathrm{~S}\right)$. When an estuarine system is open, light sulfur in continuously replenished aiding in the formation of pyrite. When the system is closed, all of the sulfate is utilized so pyrite formation ceases (Bush, Sullivan, Bush, \& Ward, 2006). This experiment could be applied to Pescadero Lagoon due to the abundance of pyrite in the sediment and the ephemeral nature of the mouth. Pyrite was measured in the sediment by taking various samples at different depths in the core and using an SEM and EDX to measure abundance. A method with a finer resolution and ability to quantify pyrite amounts easily in the sediment core should be used in order to determine when the estuary is open and closed.

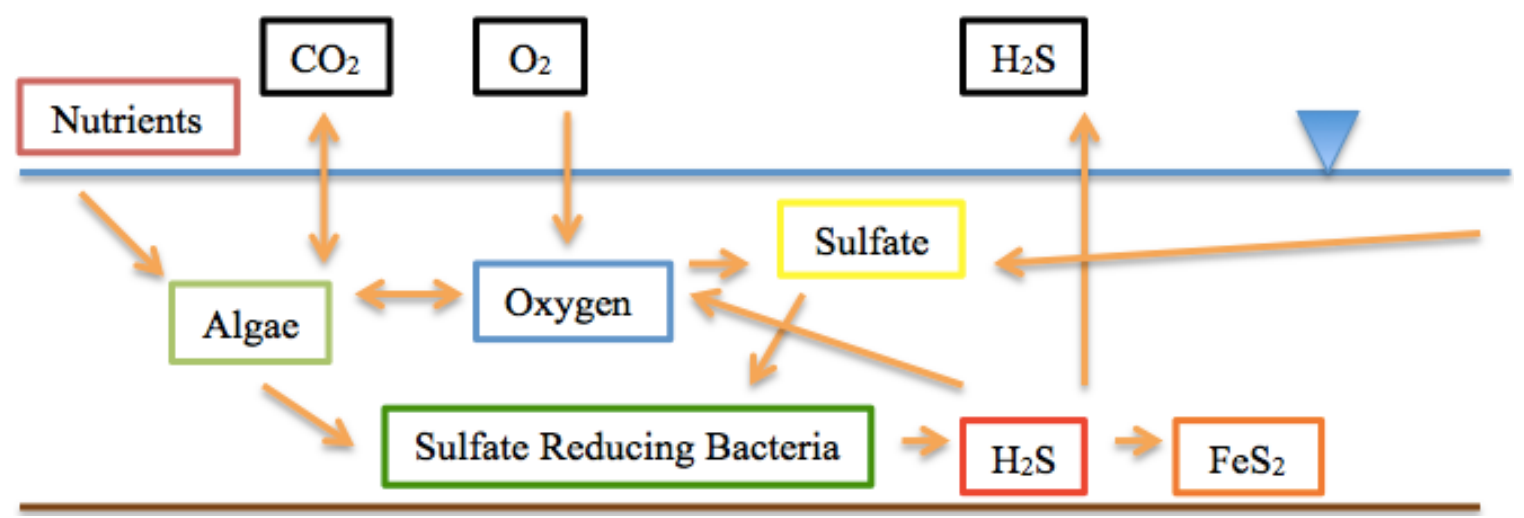

Figure 40: A conceptual model of sulfate reduction in an aquatic environment. Hydrogen sulfide and iron sulfide are produced. 


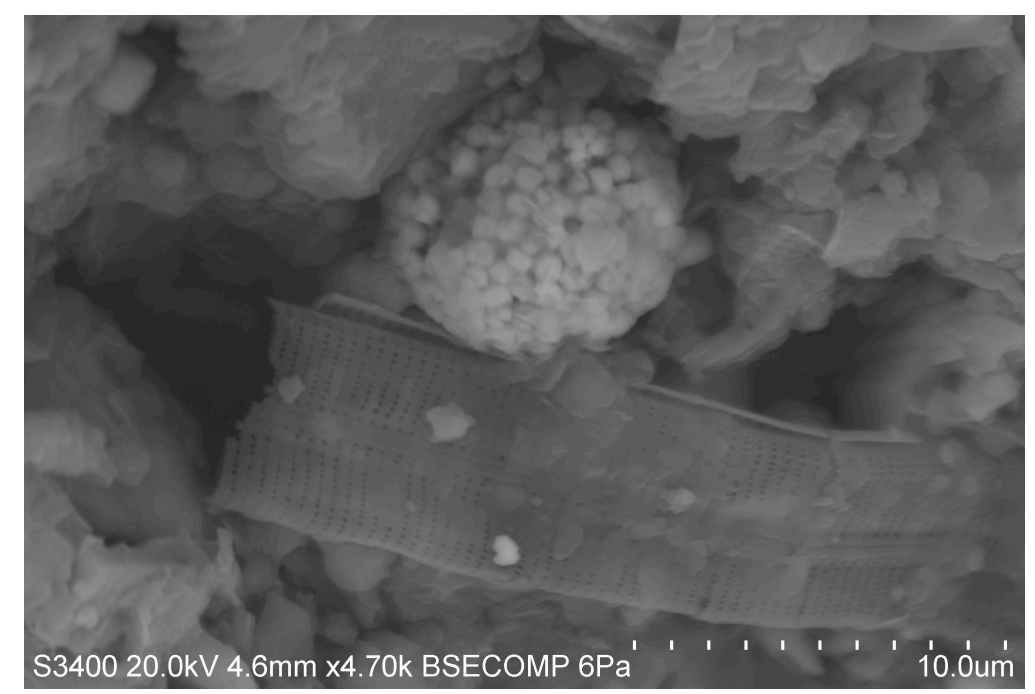

Figure 41: SEM image of a pyrite framboid above a partial pennate diatom, which was taken from the Pescadero Lagoon core, $\mathrm{C} 1$ at a depth of 25 to $27 \mathrm{~cm}$.

\subsection{Groundwater Influx}

Submarine groundwater discharge was insignificant in Pescadero Lagoon. This statement was true for March 2013 to February 2014. Due to the extreme drought conditions seen during this time period I would suggest another study to be conducted during a time of greater precipitation. Recharge is slow and there is no indication of increased groundwater flow after the sand berm broke on February 15, 2014. Another recommendation for future studies would be to capture the lag time between a significant rainfall event and a spike in groundwater flux. Groundwater recharge rate would be useful to find to see the recovery time between a stagnant environment and one with a steady freshwater input.

To see such low seepage rates into the lagoon brings into question if the extreme drought was to blame. If the same groundwater tracer methods were used over a period of time with a significant amount of rainfall by how much would the seepage rate 
increase and would similar monthly patterns be seen like in Figure 23? When the temperature method was used at Harkins Slough (70 km southeast of Pescadero Lagoon) in 2011 groundwater seepage rates exceeded $0.7 \mathrm{~m} / \mathrm{d}$ (Schmidt et al, 2011). Harkins Slough is in the same climate region and can be compared to the Pescadero Lagoon system.

The temperature method proved to be beneficial for this study, but there are some pitfalls. The ability to collect datasets from months at a time at a 15-minute frequency allows for fine resolution of a long period. The temperature signal is seen prominently at this location in the first $50 \mathrm{~cm}$, but dampens quickly the deeper the sensor is in the sediment. The locations of most of the temperature rods were placed in a clayey silt composition, which has a low permeability $\left(10^{-6}\right.$ to $\left.10^{-4} \mathrm{~cm} / \mathrm{s}\right)$. This temperature method was developed for streambed seepage. A typical streambed consists of sand to gravel sized material, which has a much higher permeability $\left(10^{-3}\right.$ to $\left.1 \mathrm{~cm} / \mathrm{s}\right)($ Fetter, 1994). Based on the soil composition of Pescadero Lagoon and the lack of rain during 2013 2014 it is understandable that the groundwater seepage rates did not exceed $0.2 \mathrm{~m} /$ day.

Groundwater is a very important resource that can affect an ecosystems health. A steady freshwater input into the system is crucial and may prevent fish kills. However, groundwater flow is difficult to restore and relies heavily on the regional climate. If future studies in the area are going to be conducted, I suggest a study to determine the main cause of lack of groundwater flow and a mitigation plan to increase flow into the system. 


\subsection{Sediment Core Analyses}

The results from sediment analyses help to comprehend the dynamics of a complex estuarine system. The core logging for $\mathrm{VC} 1$ and $\mathrm{VC} 2$ showed two different systems. VC1 represents a low energy depositional environment due to the parallel laminations and gradual changes throughout the core. Parallel laminations indicate a depositional period with no bioturbation and suggests anoxia. This area was most likely a marsh environment for most of its history. VC2 represents a dynamic environment due to its large range in grain size and drastic changes with depth. From 2 to $97 \mathrm{~cm}$ is most likely a beach bar deposit, due to the lack of organic matter and high percentage of sand. There is a drastic change at $97 \mathrm{~cm}$ to a marsh deposit and continues $134 \mathrm{~cm}$, which contains finer and darker material and a higher content of organic matter. From 134 to $202 \mathrm{~cm}$ the depositional environment switches between a riverine depositional environment with rounded coarse sand and gravel material to possible flood events composed of well-sorted clayey silt.

$\mathrm{C} 1$ was taken in a similar depositional environment to $\mathrm{VC} 1$. The sedimentation rate of $0.19 \mathrm{~cm} / \mathrm{yr}$ after $17.5 \mathrm{~cm}$ for $\mathrm{C} 1$ could also be applied to VC1. Since VC2 is dissimilar to $\mathrm{C} 1$ and $\mathrm{VC} 1$ this sedimentation rate should not be extended $\mathrm{VC} 2$, the sedimentation rate for $\mathrm{VC} 2$ is most likely nonlinear due to the dynamic nature. The large depth of the mixed layer ( 0 to $17.5 \mathrm{~cm}$ ) could indicate a seasonally drying out and then flooding of the marsh, which disturbs and redistributes the sediment.

Originally the core (C1) was analyzed for isotope activities to determine the relative age with depth. Since a linear sedimentation rate begins at $17.5 \mathrm{~cm}$ deep we can 
assume that this correlates with today's date (2013). However, since the sediment core was collected in a marsh where water and sediment flow is not consistent this assumption may not be true. Using excess isotope activities to date sediment cores works best under steady state conditions where input into the system is consistent, for example, in a river system. A study conducted by Viollis (1979) suggested that the rate of deposition is 0.21 $\mathrm{cm} /$ year, which is very similar to the sedimentation $0.19 \mathrm{~cm} /$ year calculated from my study. With this comparison we can confidently say that the sedimentation rate in Pescadero Lagoon is approximately $0.2 \mathrm{~cm} /$ year.

The main purpose for determining the sedimentation rate in the lagoon was to see if there was any compositional difference that could be found in the geologic record that would indicate an environmental shift with increasing human influence. The main time period in question is 1993 - 1995. In 1993 two projects changed the dynamic of the lagoon. In 1993 the California Department of Transportation rebuilt the Highway 1 brigde that extends over the mouth, this in turn changed the geomorphology of the mouth. A project conducted by the California Department of Parks and Recreation that started in 1993 set out to restore the hydrologic connectivity within the lagoon. Coincidentally in 1995 the fish kills began in Pescadero Lagoon. So the main purpose of age dating sediment cores was to see if there was evidence in the geologic record to provide a linkage between events.

The longest sediment cores recovered were $2 \mathrm{~m}$ long and represent approximately 1000 years of deposition, assuming a constant rate. The sediment cores show multiple facies shifts over time. However, the resolution is not fine enough to detect distinct 
changes over the past decade or so. With the sediment cores that were recovered and analyses conducted we are not able to find evidence suggesting an event or series of events changed the composition of the lagoon. There is evidence of anoxic conditions in the top $\sim 10 \mathrm{~cm}$, the sediment is black mud containing high amounts of organic matter and has a distinct sulfur smell.

The large mixed layer that spans $\sim 17.5 \mathrm{~cm}$ from the surface down in the $\mathrm{C} 1$ core is unusually large. A typical mixed layer where bioturbation is present rarely exceeds $\sim 10 \mathrm{~cm}$, which is do to the reworking of sediment by macrofauna. I would attribute the large mixed layer seen in the core to biological as well as physical mixing. The area where the core was extracted was observed to dry out and fill back in with water seasonally. The sloshing back and forth of water reworks the sediment and creates a large mix layer combined with biotubation. Since the mixed layer was unusually large we were unable to age date the sediments, however a consistent rate of deposition was found.

The sediment cores have shown a very dynamic depositional environment. Lagoons and estuaries are a fairly new environment that developed over the past 10,000 years. Sea level started to rise 11,500 years ago, which trapped sediment along the coast. As sea level rise slowed finer sediment was brought to the mouth of the estuary forming a lagoon system (Masters \& Aiello, 2007). Recently in history, Pescadero Lagoon has been functioning as an ephemeral bar built lagoon. As early as the 1940s there is record of the tides overtopping the sand berm and mixing occurred within the Pescadero creek, North Pond, and North Marsh. This was a time where little human activity would have 
interfered with the lagoon process, therefore shows a natural state of the ecosystem.

Evidence from sediment cores suggests that for over 1,000 years the wetland areas behind the lagoon have been classified as a salt marsh (Viollis, 1979).

Pescadero Lagoon has undergone many human induced stressors over time. The quality of this lagoon has degraded due to increased agricultural input, construction, erosion, and other human impairments. Figure 4 from 1943 shows a significantly greater agricultural land use than we see today and the nutrient concentrations were relatively low so contaminants from fertilizers should not have increased in the last decade. The major destructive component in this system is the lack of freshwater input. My study has shown that SGD input in nearly zero and precipitation was lacking as well. The lack of hydrologic connectivity between each component of the system and the ocean is creating a deleterious fate for the water quality and ecosystem it supports.

\subsection{Electrical Resistivity}

Resistivity surveys were conducted along the beach to find the freshwatersaltwater interface. The resistivity images suggest that when the sand berm is closed to exchange with the ocean the preferential flow path for groundwater is closest to the rock outcrop which bounds the south side of the estuary. In 2012 the sand berm was manually breached to prevent a fish kill event, the channel dug can be seen in Figure 42. This channel allowed exchange with the ocean for a short period of time but shortly closed and this opening did prevent a fish kill for that season. However, the channel may have been able to stay open for a longer period of time if the channel were dug at another location. 
All observations and data suggest that if a manual breach were necessary in the future that a more efficient channel location would be closest to the rock outcrop that bounds the south side of the mouth.

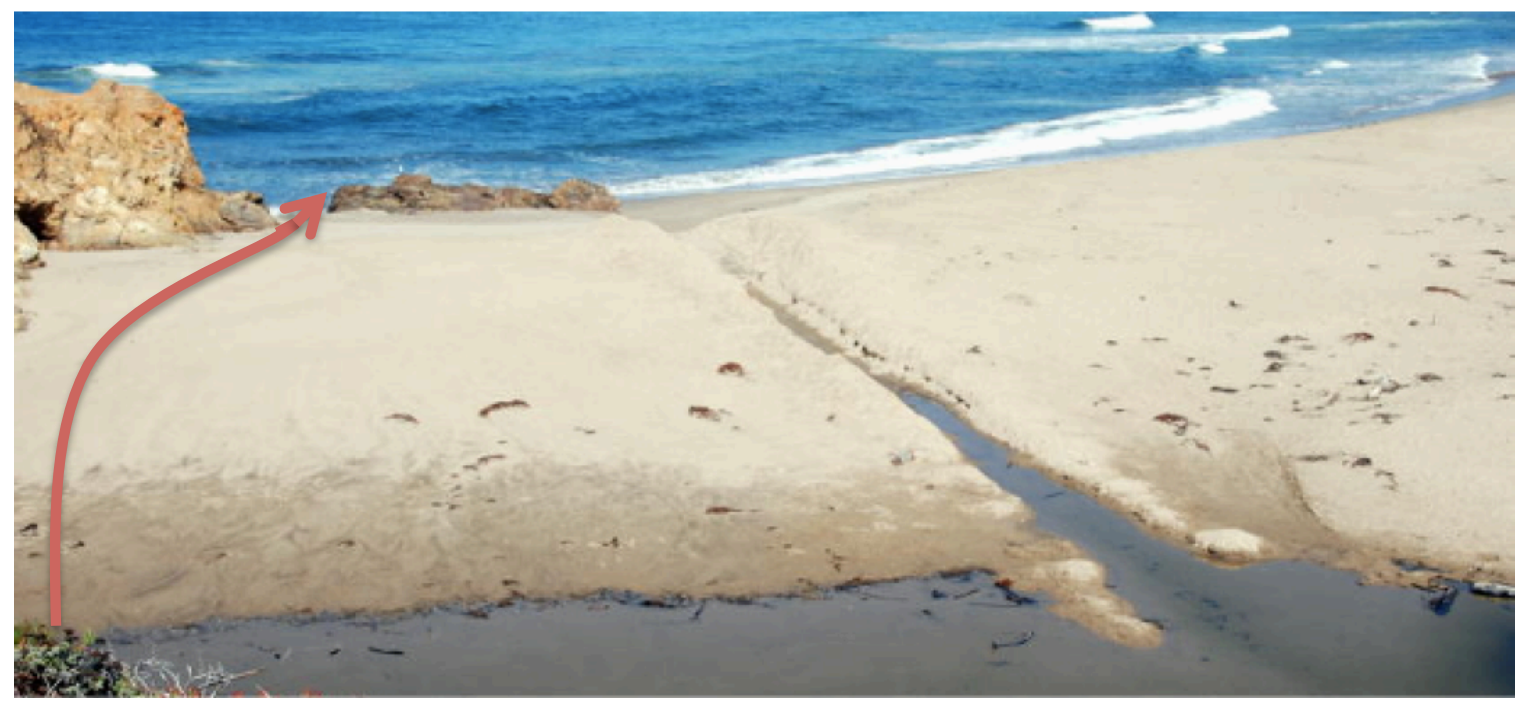

Figure 42: Manual breach of sand berm occurred on October 4, 2012 and this image was taken on October 8, 2012, which shows the channel narrowing, by October 25, 2012 the channel was completely closed. Solid red line is the suggested flow path for future manual breaches. Adapted from "Pescadero: The Saga of the Sandbar", by Coastside State Parks Association. 2012.

\subsection{Implications}

This study was conducted with the purpose to understand the dynamics of Pescadero Lagoon as well as suggest any modifications to the system based on my findings. I will stress again that this study was conducted over a drought period and a similar study should be conducted in the future with variable conditions. There are a few problems that I see need the most attention to alleviate stress on the ecosystem. The major limiting factors are the sand berm closure, lack of hydrologic connectivity, and lack of freshwater input. My suggestions for mitigation are to change the location of the manual breach at the mouth to the southern bank as well as stabilize slopes within the 
watershed to decrease erosion of slopes and increased sedimentation at the mouth. To increase hydrologic connectivity in the lagoon I suggest modification of the exisiting culverts, levees, and dykes. The lack of freshwater flow is a more difficult issue to address because it relies so heavily on the regional climate. Lack of precipitation has become an issue recently for many areas of California. Further studies would need to be done to determine why there is a lack of groundwater input and to determine the best mitigation plan. 


\section{REFERENCES}

Bencala, K. E., McKnight, D. M., \& Zellweger, G. W. (1990). Characterization of transport in an acidic and metal-rich mountain stream based on a lithium tracer injection and simulations of transient storage. Water Resources Research, 26, 9891000 .

Bredehoeft, J. D., \& Papadopulos, I. S. (1965). Rates of vertical groundwater movement estimated from the Earth's thermal profile. Water Resources Research, 1(2), 325328.

Burnett, K., Reeves, G., Miller, D., Clarke, S., Christiansen, K., \& Vance-Borland, K. (2003). A first step toward broad-scale identification of freshwater protected areas for pacific salmon and trout in Oregon, USA. JP Beumer.

Burnett, W. C., Aggarwal, P. K., Aureli, A., Bokuniewicz, H., Cable, J. E., Charette, M. a, ... Turner, J. V. (2006). Quantifying submarine groundwater discharge in the coastal zone via multiple methods. Science of the Total Environment. doi:10.1016/j.scitotenv.2006.05.009

Bush, R. T., Sullivan, L. A., Bush, M. L., \& Ward, N. (2006). Delta 34 S of discrete authigenic framboidal pyrite : A powerful palaeo-indicator for barrier estuary closure (p. 2006).

Cable, J. E., Burnett, W. C., Chanton, J. P., \& Weatherly, G. L. (1996). Estimating groundwater discharge into the northeastern Gulf of Mexico using radon-222. Earth and Planetary Science Letters, 144, 591-604.

Coastside State Parks Association. (2012). Pescadero : the saga of the sandbar. Retrieved from http://sanmateocoastnha.org/nl_pdf/fall_2012_sandbar.pdf.

Constantz, J., \& Stonestrom, D. A. (2003). Heat as a tool for studying the movement of ground water near streams. Retrieved from http://pubs.usgs.gov/circ/2003/circ1260/pdf/Circ1260.pdf

Clark, J. F., Schlosser, P., Stute, M., \& Simpson, H. J. (1996). SF6-3HE tracer release experiment: a new method of determining longitudinal dispersion coefficients in large rivers. Environmental Science \& Technology, 30(5), 1527-1532.

Dulaiova, H., Peterson, R., Burnett, W. C., \& Lane-Smith, D. (2005). A multi-detector continuous monitor for assessment of $222 \mathrm{Rn}$ in the coastal ocean. Journal of Radioanalytical and Nuclear Chemistry, 263(2), 361-365. 
Fetter, C. W. (1994). Applied hydrogeology (3rd ed.). Upper Saddle River, NJ: Prentice Hall, Inc.

Frucht, S. B. (2013). Pescadero-Butano Watershed sediment TMDL project definition and project plan.

Hatch, C. E., Fisher, A. T., Revenaugh, J. S., Constantz, J., \& Ruehl, C. (2006). Quantifying surface water-groundwater interactions using time series analysis of streambed thermal records: method development. Water Resources Research, 42. doi:10.1029/2005WR004787

Jannasch, H. W., Coletti, L. J., Johnson, K. S., Fitzwater, S. E., Needoba, J. A., \& Plant, J. N. (2008). The land/ocean biogeochemical observatory: A robust networked mooring system for continuously monitoring complex biogeochemical cycles in estuaries. Limnology and Oceanography: Methods, 6, 263-276. doi:10.4319/lom.2008.6.263

Jeter, H. W. (2000). Determining the ages of recent sediments using measurements of trace radioactivity. Terra et Aqua, 78, 21-28.

Lapham, W. W. (1989). Use of temperature profiles beneath streams to determine rates of vertical ground-water flow and vertical hydraulic conductivity.

Lee, D. R., \& Cherry, J. A. (1979). A field exercise on groundwater flow using seepage meters and mini-piezometers. Journal of Geological Education, 27(1), 6-10.

MacIntyre, S., Wanninkhof, R., \& Chanton, J. (1995). Trace gas exchange across the air-water interface and coastal marine environments. Biogenic Trace Gases: Measuring Emissions from Soil and Water, 4(24), 52-97.

Martin, J. B., Cable, J. E., Swarzenski, P. W., \& Lindenberg, M. K. (2004). Enhanced submarine ground water discharge from mixing of pore water and estuarine water. Ground Water, 42(7), 1000-1010. doi:10.1111/j.1745-6584.2004.tb02639.x

Masters, P. M., \& Aiello, I. (2007). Postglacial evolution of coastal environments. In California Prehistory: Colonization, Culture, and Complexity (pp. 35-40).

National Water Information System. USGS 11162500 PESCADERO C NR PESCADERO CA. Retrieved May 28, 2013, from http://waterdata.usgs.gov/nwis/uv/?site_no $=11162500 \&$ PARAmeter_cd $=00060,000$ 65

NOAA Fisheries West Coast Region. (2013). Pescadero steelhead can celebrate Independence Day. Retrieved March 31, 2013, from 
http://www.westcoast.fisheries.noaa.gov/stories/2013/31_2013_7_31_pescadero_ste elhead_independence_day.html

Novak, T. (2011). Nitrate transport to coastal Monterey Bay: investigating source inputs from Elkhorn Slough. California State University Monterey Bay.

Neumann, T., Rausch, N., Leipe, T., Dellwig, O., Berner, Z., \& Böttcher, M. E. (2005). Intense pyrite formation under low-sulfate conditions in the Achterwasser lagoon, SW Baltic Sea. Geochimica et Cosmochimica Acta, 69(14), 3619-3630. doi:10.1016/j.gca.2005.02.034

Reese, B. K., Anderson, M. A., \& Amrhein, C. (2008). Hydrogen sulfide production and volatilization in a polymictic eutrophic saline lake, Salton Sea, California. Science of the Total Environment, 406(1-2), 2015-218.

Robertson, E. C. (1988). Thermal properties of rocks. Reston.

Rosenberry, D. O., \& Morin, R. H. (2004). Use of electromagnetic seepage meter to invetigate temporal variability in lake seepage. Ground Water, 42(1), 68-77.

Schmidt, C. M., Fisher, A. T., Racz, A. J., Lockwood, B. S., \& Huertos, M. L. (2011). Linking Denitrification and Infiltration Rates During Managed Groundwater Recharge. Environmental Science \& Technology.

Sloan, R. M. (2006). Ecological investigations of a fish kill in Pescadero Lagoon, California. San Jose State University.

Smith, K. A. (2009). Inorganic chemical oxygen demand of re- suspended sediments in a bar-built lagoon. San Jose State University. Retrieved from http://scholarworks.sjsu.edu/cgi/viewcontent.cgi?article $=4342 \&$ context=etd_theses \&sei-

redir=1\&referer=http $\% 3 \mathrm{~A} \% 2 \mathrm{~F} \% 2 \mathrm{Fwww}$.google.com $\% 2 \mathrm{Furl} \% 3 \mathrm{Fsa} \% 3 \mathrm{Dt} \% 26 \mathrm{rct} \% 3$ Dj\%26q\%3Dpescadero\%2Blagoon\%2Bsjsu\%26source\%3Dweb\%26cd\%3D3\%26ve d\%3D0CEMQFjAC\%26url\%3Dhttp\%253A\%252F\%252Fscholarworks.sjsu.edu\%2 52Fcgi\%252Fviewcontent.cgi\%253Farticle\%253D4342\%2526context $\% 253$ Detd th eses\%26ei\%3DpTKLUZXwG4qUiQLahIDwCg\%26usg\%3DAFQjCNH_U37gyrhT 502DSpWJfcIN4Z60wA\%26sig2\%3DoPGWgex9jBGQY5_0CvgZ3w\#search=\%22 pescadero lagoon sjsu\%22

Strickland, J. D. H., \& Parsons, T. R. (1972). A practical handbook of seawater analysis (2nd ed.). Ottawa: Fisheries Research Board of Canada.

Smoak, J. M., \& Swarzenski, P. W. (2004). Recent increases in sediment and nutrient accumulation in Bear Lake, Utah / Idaho, USA. Hydrobiologia, (525), 175-184. 
Swarzenski, P. W. (2007). U/Th series radionuclides as coastal groundwater tracers. chemical reviews, 107(2), 663-674.

Swarzenski, P. W., Reich, C., Kroeger, K. D., \& Baskaran, M. (2007). Ra and Rn isotopes as natural tracer of submarine groundwater discharge in Tampa Bay, Florida. Marine Chemistry, 104, 69-84.

Swarzenski, P. W., Simonds, F. W., Paulson, A. J., Kruse, S., \& Reich, C. (2007). Geochemical and geophysical examination of submarine groundwater discharge and associated nutrient loading estimates into Lynch Cove, Hood Canal, WA.

Environmental Science \& Technology, 41(20), 7022-7029.

USDA, Agricultural Adjustment Administration. (1943). San Mateo County, California Aerial Photography -1943, DDB-2B-157. UC Berkley Library. Retrieved February 18,2013 , from

http://ucblibrary3.berkeley.edu:8085/AerialPhotos/airphotoddb/DDB-5.html

Viollis, F. S. (1979). The evolution of Pescadero Marsh. San Francisco State University.

Wilkin, R. T., \& Barnes, H. L. (1996). Pyrite formation by reactions of iron monosulfides with dissolved inorganic and organic sulfur species. Geochimica et Cosmochimica Acta, 60(21), 4167-4179. 